\title{
Economic Assessment of Use of Pond Ash in Pavements
}

Raju Sarkar*1, A. R. Dawson ${ }^{2}$

${ }^{1}$ Department of Civil Engineering, Delhi Technological University Delhi, India

${ }^{2}$ Nottingham Transportation Engineering Centre, University of Nottingham, Nottingham, U.K.

*Corresponding author

Delhi Technological University, Delhi, India

Bawana Road, Delhi - 110042

Email address: rajusarkar@dce.ac.in

Tel.:+91-11-27871029; Fax: +91-11-27871023 


\section{ABSTRACT}

The paper introduces a new type of industrial waste based subbase material which can replace conventional subbase material in pavement construction. Utilization of this industrial waste, namely pond coal ash produced from a thermal power plant in road construction will help to reduce the disposal problem of this waste and also will help to reduce the problem of scarcity of conventional subbase material. Lime and fibre were also added to the pond ash at various percentages to improve the suitability of this type of mix as subbase material. The optimum service life of pavement is studied with the help of numerical modeling and the cost benefit is also presented in the current study. The study reveals that stabilization of the coal ash with $2 \%$ lime may produce an optimal material and, even though a greater thickness may be required to deliver the same pavement performance, direct cost savings of around $10 \%$ may be achieved in additional to less easily quantifiable environmental benefits. Design charts are provided to exploit the findings.

\section{Keywords:}

Pond ash, geotechnical characterization, numerical analysis, economic assessment

\section{INTRODUCTION}

One of the major challenges facing the manufacturing and processing industries is the disposal of residual waste products. Ash, resulting from the combustion of coal to produce electricity, is a readily available by-product - particularly in India, the focus of this paper. As this availability is becoming more appreciated, demand for economic pavement construction materials, that impose a low environmental impact, is rapidly growing. Therefore, ash is considered in this paper as an alternative sub-base material. Though a powdered material, but, due to its pozzolanic properties and when stabilized with cement, it might be made to meet the requirements of cement bound sub-base material. Alternatively, lime could be used instead of cement, to give comparable long term 
strengths (Sherwood, 1995) albeit less rapidly developed (Atkinson et al, 1999). Fibre-reinforcement is another possible improvement strategy (Kumar and Singh, 2008).

Thus the aim of this paper is to provide means of reliably incorporating ash, as found in disposal ponds at Indian power stations, into viable layers of pavement construction. The paper draws on laboratory test data reported earlier, using this data to numerically compute likely in-situ behaviour. The aim is ultimately achieved by the production of design charts to guide users to the appropriate material and thickness of pavement layer incorporating that material and by providing an illustrative cost comparison.

\section{PAVEMENT LAYER PRACTICE AND MATERIALS USED}

In India, in practice, flexible pavements are considered to act as a three layer structure - sub-grade, unbound (so-called) and bound layer. The lowest part of the unbound layers, which is just above the sub-grade layer, is commonly known as the sub-base layer of the pavement. The higher 'unbound' layer usually comprises a Water Bound Macadam (WBM) or a Wet Mix Macadam (WMM) that forms the pavement base layer. While no cementing agent is added, compaction and water combine to provide a material held together by physical interlock and suction. It lies just above the sub-base layer. The bound layer is usually divided into two parts, viz., the Dense Bituminous Macadam (DBM) that lies above WBM and the top layer, known as Bituminous Concrete (BC) or wearing course. The subgrade layer is made up of locally available soil. The sub-base layer is typically formed of unbound granular materials viz. natural sand, moorum, gravel and or crushed stone based on a combination of availability, economic factors and previous experience. The commonly used materials for the WBM layer are crushed, graded aggregate and granular material, premixed with water. Crushed stone is also used as coarse aggregate. A DBM is a binder course in which bitumen binds together a mixture of coarse and fine aggregate. The top bituminous layer (BC) comes directly 
into contact with the vehicle tyres. It consists of a mixture of aggregates and sufficient bitumen so that it provides an impermeable barrier to water percolation (Chakroborty and Das, 2003).

\section{ENVIRONMENTAL CONSIDERATIONS WHEN USING CONVENTIONAL MATERIALS}

The most common materials that are used in road construction are bitumen, aggregate, crushed rock, sand and gravel. New bitumen is an oil product and, hence, its abstraction from the ground incurs similar issues as those associated with obtaining fossil fuels. However, it is a recyclable material; it can be used repeatedly by reheating it, allowing the asphalt that it binds to be softened, reworked and replaced. But the initial heating and subsequent reheating and recycling requires large amounts of heat energy and produces lots of harmful green house gases which pollutes the environment. Again in summer, temperature rises and thus bitumen becomes soft. Natural solar heating will also causes softening of the bitumen, resulting in asphalt bleeding, rutting and segregation, and hence to failure of the pavement. During winter, temperature reduces, the bitumen becomes brittle and cracking, ravelling and unevenness can result.

The other materials used in pavement construction are the products of mining. While requiring relatively low energy to produce and lay, haul costs (i.e., fuel, labour, and maintenance) are the single largest variables in determining the cost of material in road construction. To limit these costs, sand and gravel mines are often opened near to a specific road project and then abandoned once the project is completed (Blodgett, 2004), leading to widespread despoliation and degraded air quality at the mining site and its vicinity. Aggregate and sand mines require water to wash some of its product and to control dust on site. To fulfil this demand many use scarce ground water competing undesirably with the increasing demands of domestic water use. 


\section{$4 \quad$ SITUATION IN INDIA}

At present the National Highway network consists of about $71,772 \mathrm{~km}$, comprising only $1.7 \%$ of the total length of roads in India, but carries over $40 \%$ of the total traffic across the length and breadth of the country (MORT\&H, 2011). To alleviate congestion and to provide for future development, the Government of India has recently launched an extensive road construction programme under which thousands of kilometres of roads are currently under construction or scheduled for construction in the future. Current methods to be used for the construction of the new roads are not as per international standards. As an example, India is still using very small amounts of recycled aggregate material for road construction. Instead it mostly depends on conventional materials viz. aggregate, crushed rock, sand and gravel.

As reviewed above, such materials are associated with considerable problems. Thus, to counteract these problems, India needs to focus on recyclable aggregate material or must replace conventional sub-base or base materials with alternative materials. These materials could be industrial and domestic waste products since these materials are cheaply available and their use in road construction provides an efficient solution to the associated problems of pollution and disposal of these wastes.

Thermal power is the chief source of energy and produces nearly 70 percent of total energy production in India. Over 100 million tons per year (Gulhati and Datta, 1999) of coal ash is generated by these thermal power plants. Due to high ash content of coal along with a low percentage utilization of the fly ash, most of the fly ash is disposed of on land by creating an engineered ash pond to take care of environmental concerns. While many European countries and Japan use more than 50 percent of fly ashes in an environmentally acceptable manner, India has a modest record of only 5 percent utilization (Subbarao et al., 2001). The disposal of the fly ash is a serious hazard to the environment and consumes millions of rupees and many hectares of precious land. 
Pond ash is the fly ash, as well as the bottom ash, produced by a power plant when it is disposed of in an ash pond in the form of a slurry, typically at a ratio varying between 1 part ash to 6-10 parts of water. Pond ash is a non-crystalline pozzolanic and slightly cementitious material. On the basis of these properties, it might be converted into meaningful wealth as an alternative construction material in civil engineering works (Sarkar et al, 2012). Use of pond ash in pavement construction could allow it to be used in large quantities. Therefore, this paper addresses its potential, stabilized both with and without fibres.

\section{OPPORTUNITIES FOR REPLACING CONVENTIONAL MATERIALS BY ASH PRODUCTS}

There are numerous successful case histories on the utilization of fly ash either alone or mixed with other material. Typically, fly ash has been used for soil stabilization in road pavements - Chu et al (1995); as embankment material - Raymond (1961); as structural fill - DiGioia and Nuzzo (1972); for injection grouting - Joshi et al(1981); as a replacement to cement - Gopalan and Haque (1986). Maser et al (1975) reported successful studies on fly ash-cement mixture for subsidence control. Fawconnier and Kersten (1982) reported that the use of pulverized fly ash filling had effectively stabilized mines, reducing the risk of pillar failure in areas of low safety factor. Galvin and Wagner (1982) observed improved strata control using fly ash fill. Palariski (1993) reported the use of fly ash, mill tailings, rock and binding agents to make consolidated backfill material to improve extraction percentage in coal mines.

Mixing of a predetermined amount of fibre to a soil, gives a mesh like configuration leading to a mechanical means for reinforcement of the matrix, if done at appropriate moisture content (Nataraj and McManis, 1997). Tests were carried out on the soils in which fibres were oriented in particular directions by Bauer and Fatani (1991), and Shewbridge and Sitar (1989). Tests were also carried out by Hoover et al.(1982), Setty and Rao (1987), Gray and Maher (1989), Maher and Gray 
(1990), Maher and Ho (1994), Michalowski and Zhao (1996), Consoli et al. (1998), and Santoni and Webster (2001) with randomly oriented fibres in soils. There, however, have been very few studies that have on fibre-reinforced and stabilized pond ash. Experimental studies have been carried out on some Indian fly ashes mixed with randomly oriented fibres. Chakraborty and Dasgupta (1996) studied the strength characteristics of polymer fibre-reinforced fly ash through triaxial shear tests. Kaniraj and Havanagi (2001) carried out experiments on randomly oriented fibre-reinforced fly ashsoil mixtures.

Dawson and Bullen (1991) investigated the engineering properties and possible use of furnace bottom ash as a sub-base material. Index and large scale pavement facility testing of furnace bottom ash in the laboratory and outdoor were carried out in this and subsequent investigations. Lee and Fishman (1993) studied the resilient and plastic behaviour of classifier tailings and fly ash mixtures. Results from cyclic tri-axial testing were used to study the resilient and plastic response of fly ash, classifier tailings, and a mixture of the two materials. Gray et al (1994) evaluated a cementstabilized fly ash base. In their study, the performance of compacted, aggregate-free, cement stabilized fly ash beneath a highway shoulder was established. A field evaluation of pavement sections containing cement-treated bases with and without fly ash was undertaken by Ksaibati and Conklin (1994). In the study, pavement performance models were developed on the basis of the physical attributes of the sections. Dawson et al (1996) used various combinations of secondary aggregates and binders in pavement foundations. They proposed various methods and procedures for the standard assessment of secondary materials viz. fly ash mixed with gypsum and lime, fly ash mixed with cement kiln dust and granular blast furnace slag and some combination of china clay and coarse aggregate. Ksaibati and Bowen (2001) undertook a wide range of laboratory testing in order to evaluate the feasibility of incorporating bottom ash into a crushed based material. Singh and Kumar (2005) studied the utilization of fibre-reinforced fly ash in road sub-bases. Singh and Ramaswamy (2005) investigated the utilization potential of cement stabilized fly ash and granulated 
blast furnace slag (GBFS) mixes in highway construction. Mishra and Karanam (2006) carried out geotechnical characterization of fly ash composites for backfilling mine voids. Chand and Subbarao (2007) carried out experiments on strength and slake durability of lime-stabilized pond ash. They attempted to check strengthanddurabilityaspectsoflime-stabilizedpondashtodetermineitssuitabilityfor base and subbase courses of pavements. Titi et al (2009) studied the resilient characteristics of bottom ash. The main aim of their research was to evaluate the characteristics of coal combustion bottom ash for potential utilization as pavement construction materials.

From the above literature review, it is seen that fly ash can be used as a direct replacement material for unbound layers (sub-base or base) of a pavement, with or without admixtures. Very little or no work has been done on the behaviour of the pavement structures incorporating various thicknesses of such ash as candidate layers for a pavement.

Another challenge is to determine the appropriate thicknesses of different layers to get the optimum pavement thickness. This challenge is important as, otherwise, service life or cost of construction of the pavement section may be intolerable. The cost of construction may be less due to the reduction in thickness of a particular layer of pavement, but if the service life is less, then the assumed benefit may, in practice, turn out to be a deterioration.

\section{$6 \quad$ AIM AND SCOPE OF WORK}

The aim of this work is to determine ways of using coal pond ash as a subbase material in road construction that deliver adequate structural performance and that are economic. To achieve this general aim, an experimental study was carried out to understand the behaviour of pond ash mixed with admixtures, namely, fibre and lime. The purpose of mixing these additives with pond ash is to improve the strength, deformability, volume stability (shrinking and swelling), permeability, erodibility, durability, etc., of the mix for their use in the pavement construction. The pond ash was 
characterized with respect to its physical and geotechnical behaviour. Proctor compaction and triaxial tests were carried out on pond ash alone and also after stabilization of the pond ash by the addition of different percentages of the above admixtures within practical limits. The optimum percentage of the above admixtures was chosen based on these tests. Important geotechnical properties such as modulus of elasticity, cohesion and an angle of shearing resistance to be used in the numerical analysis were also evaluated from the test results.

Numerical studies on the performance of pavements constructed using these pond ashes, mixed with fibre and lime, were then carried out to evaluate the design life of pavements. A nominal pavement structure was designed considering Delhi silt as the sub-grade soil. A stress-strain analysis was then performed, considering that the sub-base layer is made up of pond ash stabilized with both admixtures, using the commercially available finite element software 'PLAXIS'. A parametric study was performed by varying the thickness of different layers with respect to a reference structure for each subbase material (pond ash + admixtures). Design charts were produced for different conditions including that of "equal design life" based on the above parametric study. Finally, cost comparisons of the different pavement structures were carried out.

\section{MATERIALS USED}

\subsection{Pond Ash}

The pond ash samples used in the present research work were obtained from the Badarpur plant site of the National Thermal Power Corporation located in the National Capital Region - Delhi. Pond ash is a pozzolanic material and can be stabilized with fibres and lime. The purpose of mixing these additives with pond ash is to improve the strength, deformability, volume stability (shrinking and swelling), permeability, erodibility, durability, etc., of the mix for its use in pavement construction. 
The chemical and geotechnical properties of the pond ash sample used in this study are given in Tables 1 and 2, respectively.

\subsection{Fibre}

A recent technique of soil or pond ash improvement is the mixing of randomly oriented fibres to the soil or pond ash (Chakraborty and Dasgupta, 1996). The process is similar to the stabilization by using admixtures i.e., discrete fibres are simply added and mixed with the pond ash. The compaction characteristics of fibre-reinforced pond ash do not differ significantly from unreinforced specimens (Kumar et al, 1996). One of the main advantages of randomly oriented fibres is the maintenance of strength isotropy and absence of potential plane of weakness, which may develop parallel to oriented reinforcements. The physical and engineering properties of the polypropylene fibres used in this study are listed in Table 3.

\subsection{Lime}

Calcium oxide $(\mathrm{CaO})$ is a chemical compound, widely used to treat soils in the form of quicklime $(\mathrm{CaO})$, hydrated lime (calcium hydroxide $-\mathrm{Ca}(\mathrm{OH})_{2}$, or as a lime slurry. Quicklime is manufactured by high temperature transformation of calcium carbonate (limestone $-\mathrm{CaCO}_{3}$ ) into calcium oxide. Hydrated lime is created when quicklime chemically reacts with water. Hydrated lime reacts with silicates and aluminates in fly ash and clay particles and permanently transforms them into a strong cementitious matrix. The lime used in the present study was procured from the open market in the form of quicklime. This lime was then mixed with pond ash and water in the required proportions, by weight. Since the lime was procured from the open market, it is expected that its chemical composition will be similar to that given in Table4. 
The values of density, shear parameters and modulus of elasticity for different materials are given in Table 7.

\section{EXPERIMENTAL INVESTIGATIONS}

Fibre was added to the pond ash at an increasing percentage of $0.2,0.3,0.4$ and 0.5 . Similarly the lime was added with the pond ash at an increasing percentage of 2,3 , and 5 . The details of the experimental program are summarized in Table 5. The tests were performed conforming to the specifications given in Table 6.

\section{STRUCTURAL ANALYSIS}

\subsection{Pavement Section}

First, a typical pavement structure was designed with the selected sub-grade material having a CBR equal to $9 \%$ and to carry a traffic load of 100 million standard axles (msa) as per IRC: 37-2001. This pavement structure is shown in Fig. 1.

\subsection{Modelling Details}

The following assumptions are made in the analysis:

- All layers have finite thickness including the bottom layer (sub-grade).

- All layers are of finite extent in the lateral direction (even though infinite in extent in reality)

- Bituminous concrete (BC) and dense bituminous macadam (DBM) exhibit linear elastic response.

- Water bound macadam (WBM), sub-base and subgrade soils exhibit an elasto-plastic response and failure can be modelled using the Mohr-Coulomb constitutive relationship. 
The pavement section was modelled as suggested by Huang (1993) to mechanistically solve the layered pavement response to traffic loading and to investigate the effect of sub-base material on flexible pavement design. The pavement section considered for the finite element modelling is shown in Fig.2. A pressure of $575 \mathrm{kPa}$ was applied at the surface distributed over a radius of 150 $\mathrm{mm}$ based on specifications of the Indian Road Congress. This uniform pressure is caused by a single wheel load of $40.8 \mathrm{kN}$. Dimensions of the axisymmetric finite element model employed were selected so that it was sufficiently large and, thus, the constraints imposed at the boundaries will have very little influence on the stress distribution in the system. Based on a small parametric study, this necessitated that the right boundary be placed $1100 \mathrm{~mm}$ from the outer edge of loaded area, which is more than 7 times the radius of the applied load. The bottom extent of the subgrade was fixed at a subgrade depth of $500 \mathrm{~mm}$, based on usual practice (IRC: 37-2001). Roller supports were provided along the axis of symmetry to achieve the condition that radial displacements are equal to zero. Also, the roller supports were provided along the right boundary which was placed sufficiently away from the centre of loading. At the bottom boundary, roller supports were provided for permitting free movement in the radial direction and a restraint to any movement in the vertical direction.

During the generation of the mesh, clusters were divided into triangular elements. The meshes are composed of 15-noded triangular elements which have a greater ability to model continuously varying stress-strain fields for less computational effort than would be needed using a far greater number of 6-noded triangular elements. Results were found to converge for the adopted mesh as shown in Fig. 2.

The finite element analysis of the pavement system was carried out by considering values of resilient modulus, E, and Poisson's ratio, v, given in Table 7. The pond ash collected from the Badarpur site, as well as the pond ash stabilized with admixtures, was considered as the sub-base material in the present study. The adopted properties of these materials are summarized in Table 7. 
The resilient modulus of the subgrade has been calculated as per IRC: 37-2001. In India, coarse sand or a mixture of river bed material and crushed stones are commonly used as a conventional subbase material (CSM) for pavement construction (Sinha, 2009). The properties of conventional sub-base material (CSM) are derived from the investigations of Lee et al (2001) and Shodhganga (2006). Titi et al (2009), Kumar and Singh (2008) and Ornebjerg et al (2006) considered the value of resilient modulus of alternative subbase material, bottom ash and fly ash, similar to those being considered in this paper, obtaining values within the range 60-70 MPa. So, in the present study, the value of resilient modulus of pond ash was taken as $70 \mathrm{MPa}$. Similarly, Kumar and Singh (2008) considered the value of resilient modulus of fly ash mixed with fibre of $0.2 \%$ and $0.3 \%$ as $102.36 \mathrm{MPa}$ and $142.35 \mathrm{MPa}$. So in the present study, for simplicity, the values of pond ash mixed with fibre $0.2 \%, 0.3 \%, 0.4 \%$ and $0.5 \%$ are considered to be $100 \mathrm{MPa}, 140 \mathrm{MPa}, 160 \mathrm{MPa}$ and $170 \mathrm{MPa}$ respectively. Potentially the moduli of the mixes with higher moduli could be underestimated. In the case of pond ash mixed with lime, the resilient modulus is calculated by considering the initial tangent modulus of the triaxial stress-strain graph for material 7 days old and subject to a confining stress of $100 \mathrm{kPa}$. The properties of WBM are considered on the basis of studies of Dawson et al (1996) and Theyse (2002). Loulizi et al (2006) tested hot-mix asphalt specimen from $-15^{\circ} \mathrm{C}$ to a maximum temperature of $40^{\circ} \mathrm{C}$ to determine the resilient modulus of hotmix asphalt. So a small extrapolation was performed to determine the resilient modulus of hot-mix asphalt for a temperature of $45^{\circ} \mathrm{C}$ (assuming the maximum temperature during the summer period). The elastic modulus for bituminous concrete is considered as per IRC: 37-2001.

\subsection{Parametric Study}

To develop design charts to help in decision making and better utilization of the technique of pond ash stabilization by admixtures, a detailed parametric study was carried out by considering the nominal pavement as the reference structure and then varying the thickness of each layer within practical limits with respect to this nominal pavement, as given in Table 8. Other materials 
considered for subbase layer were as follows: Badarpur pond ash mixed with percentage of fibre and lime as mentioned in Table 7 and CSM. Given the expectation that stabilized ash might not perform so well as a CSM, greater thicknesses of this were considered than that of the CSM in the reference pavement. Also, since the ash-based material is expected to be economic compared with the base and asphaltic layers, greater thicknesses of the ash layer might allow thinner layers of the higher pavement layers, introducing the possibility of overall cost savings.

\subsection{Design Life of Pavement}

Structural failures in a flexible pavement are of two main types, namely, surface cracking and rutting.

9.4.1 Rutting: As per IRC: $37-2001$, the occurrence of a rut depth of $20 \mathrm{~mm}$ is considered as the failure criterion. The design life or service life of a pavement is defined in terms of the cumulative number of standard axles that can be carried before strengthening of the pavement is necessary. The following equation is proposed in IRC: $37-2001$ to calculate the design life on account of rutting failure alone:

$$
\mathrm{N}_{\mathrm{R}}=4.1656 \times 10^{-8}\left[1 / \epsilon_{\mathrm{v}}\right]^{4.5337} \quad \text { Eq. } 1
$$

Where, $\mathrm{N}_{\mathrm{R}}=$ Number of cumulative standard axles to produce rutting depth of $20 \mathrm{~mm}$ and $\epsilon_{\mathrm{V}}=$ Maximum vertical compressive strain at the top of subgrade in microns.

A service life ratio (SLR) as given below can be used to compare the effect of subbase material type on service life of a pavement:

$$
\operatorname{SLR}=\mathrm{N}_{1} / \mathrm{N}_{2}
$$

and using Eq. (1), 


$$
\operatorname{SLR}=\left[\epsilon_{\mathrm{v} 2} / \epsilon_{\mathrm{v} 1}\right]^{4.5337}
$$

Where, $\mathrm{N}_{1}, \mathrm{~N}_{2}=$ Number of passes of a standard axle required to produce allowable rutting in a pavement with subbase material type 1 and 2 , respectively, and

$\epsilon_{\mathrm{v} 1}, \epsilon_{\mathrm{v} 2}=$ Vertical compressive strain at the top of subgrade layer with subbase material type 1

and 2 , respectively

In the following analyses, subbase 1 is taken to be the one comprising CSM, $200 \mathrm{~mm}$ thick.

9.4.2 Fatigue: In a similar manner, a service life ratio (SLR) can be computed for fatigue failure. The actual relationship will depend on the material that is subject to fatigue. For the purpose of this paper, the fatigue characteristics determined by IRC: 37-2001 for a DBM were adopted:

$\operatorname{SLR}=\left[\epsilon_{\mathrm{t} 2} / \epsilon_{\mathrm{t} 1}\right]^{3.89}$

Eq. 4

Where, $\epsilon_{\mathrm{t} 1}, \epsilon_{\mathrm{t} 2}=$ Tensile strain at the bottom of the bound DBM course with subbase material type 1 and 2, respectively

\section{TEST RESULTS AND DISCUSSION}

Figs. 3 (a)-(b) plot the maximum vertical compressive strain at the top of the subgrade versus sub-base thickness for the cases when the subbase layer is made up of Badarpur pond ash alone and mixed with fibre and lime, respectively, having the properties as given in Table 8, which vary with stabilization rate. The magnitude of the maximum subgrade strain decreases with the increase in subbase thickness and with degree of stabilization. The thicknesses of all layers except the subbase are maintained at their reference values (see Table 8). The magnitude of the vertical strain is simply and positively related to the rutting in the pavement. The lesser the value of the maximum vertical 
compressive strain in the subgrade, the lesser is the rutting in the pavement and the longer is the life of the pavement.

It can be seen that, for fibre-stabilization, improvement continues until $0.3 \%$ fibre has been added but then, adding more fibre, causes little further benefit. In the case of lime, $2 \%$ addition achieves significant reductions in strain whereas additional lime-stabilization achieves little further benefit.

Fig. 4(a)-(c) shows the vertical compressive strain at the top of subgrade when the thickness of the subbase and of the bound courses (WBM and DBM) are varied. In each case the subbase course is made up of pond ash stabilized with the preferred percentages of each admixture as mentioned above. For each arrangement, Fig. 4(a)-(c) shows that the pond ash stabilized with $0.5 \%$ fibre gives the minimum strain (i.e. the shortest life). As expected, the maximum strain is obtained when the pond ash is used without any stabilizer.

Figs. 5 (a)-(b) shows the plots of the maximum tensile strain at the bottom of the DBM and subbase thickness behaviour for the cases when the subbase layer is made up of Badarpur pond ash mixed with fibre and lime, respectively, in the same percentages as mentioned above. The magnitude of the maximum tensile strain decreases with the increase in subbase thickness. For any particular type of bound material, the magnitude of the tensile strain is simply and positively related to the cracking in the pavement. The lesser the value of the tensile strain at the bottom of the DBM, the lesser is the cracking in the pavement and thus longer is the life of the pavement.

Fig. 6 compares the minimum tensile strain at the bottom of the DBM with varying subbase thickness for the cases when the subbase layer is made up of pond ash stabilized with those percentages of each admixture that gave the probable optimal improvement in rutting behaviour $(0.5$ $\%$ fibre and $2 \%$ lime) as well as for reference cases. As for the vertical subgrade strain, Fig. 6 shows that the pond ash stabilized with $0.5 \%$ fibre gives the minimum tensile strain. Similarly, as for the 
case of vertical strain at the top of subgrade, the maximum tensile strain is obtained when the pond ash is used without any stabilizer.

The values of vertical compressive subgrade strain $\epsilon_{\mathrm{v}}$ and tensile strain at the bottom of the bound, DBM, course, $\epsilon_{\mathrm{t}}$ as picked from Figs. 3(a)-(b) and Figs. 5(a)-(b), for the structures including the range of selected subbase, are given in Table 9. The corresponding service life ratio (SLR) for different pavement sections was evaluated using Eq. (3). The maximum SLR following stabilization of a $200 \mathrm{~mm}$ thick subbase layer are 1.79 and 0.82 (considering vertical compressive strain), and 1.56 and 0.75 (considering tensile strain) respectively for $0.5 \%$ fibres and $2 \%$ lime treatments, respectively. Thus, for the same thickness of ash subbase, treatment by fibres, but not by lime, yields a service life ratio that is higher than that for the conventional subbase. Vertical strains and tensile strains for pond ash alone and mixed with lime are much higher than that for conventional subbase material (CSM) and so the service life ratios are much lower than CSM. For all three alternatives given in Table 9, it is the tensile strain at the bottom of the asphaltic layers which is the limiting condition.

From Fig. 7, which plots this SLR data, it is observed that the stiffness ratio (i.e. stiffness of ash compared to stiffness of CSM) increases monotonically with the increase in the service life ratio when the pond ash is mixed with various percentages of fibre and lime and used as subbase material.

The inverse of the above - the variation in the thickness of different layers of a pavement having a stabilized subbase layer needed to provide the same lifetime of the pavement as the conventional pavement is given in Table 10. As per IRC: 37-2001, the required thickness of the subbase layer for a traffic of $100 \mathrm{msa}$ and for a CBR value of subgrade material of $9 \%$ is $200 \mathrm{~mm}$ when CSM is used as the subbase material. Thus it needs to be increased to $315 \mathrm{~mm}$ when pond ash alone is used as the subbase material if the service life of the pavement is to remain unaffected (column 2 and 3 of Table 10). This increased thickness for the same service life is termed as equivalent thickness. The problem of a thick pavement section in such cases can be easily overcome 
by keeping the subbase thickness of $200 \mathrm{~mm}$ the same (as per design) but increasing the thickness (usually by a much smaller amount) of either the WBM layer or the DBM layer (as shown in the last 4 columns of Table 10). The decision of such replacement will naturally be guided by economy of construction.

Fig. 8 depicts the equivalent thickness of subbase, WBM or DBM layers that will give the same service life ratio; in each case the other layers retain their reference thickness. The procedure to pick equivalent thickness is illustrated in Fig. 8(b). e.g. when the WBM thickness would be 240 $\mathrm{mm}$ over a CSM, its thickness can be reduced to $140 \mathrm{~mm}$ if an ash $+0.5 \%$ fibre is used as the subbase or must be increased to $445 \mathrm{~mm}$ if the ash is used unstabilized (see dashed lines on Fig. 8(b)). The results are summarized in Table 10.

\section{ECONOMIC ASSESSMENT}

In the present study, the pavement is designed for a single subgrade soil. The various layers are considered as shown in Fig. 1. Based on assumption made by Central Road Research Institute (CRRI), Delhi (2009) on daily commercial traffic volume of a major part of Delhi, the design data for the cost analysis in the current study is assumed as follows:

Initial traffic in the year of completion of construction $\quad=100 \mathrm{msa}$

Design life $\quad=15$ years

CBR value of subgrade (Table 7) $=9 \%$

The pavement was designed as per IRC 37:2001 and a pavement thickness of $635 \mathrm{~mm}$ was obtained as shown in Fig. 1. Based on IRC 86:1983, the other details were assumed as given below:

Top width of embankment

Side slope

Length of embankment

$$
\begin{aligned}
& =3750 \mathrm{~mm} \\
& =2 \mathrm{H}: 1 \mathrm{~V} \\
& =1000 \mathrm{~m}
\end{aligned}
$$


For simplicity, the cost of the preparation of subgrade, conventional subbase material subbase, granular base, dense bituminous macadam and bituminous concrete is considered to be the same in all cases and were taken from Tirumala (2007). However, the cost of the preparation of different subbase layer varies, depending upon the thickness and the material of the subbase. The current schedule of rates for Delhi region is used for the cost analysis of subgrade, subbase, WBM, DBM and BC course.

The details of the cost analysis per $\mathrm{m}^{3}$ for subgrade are shown in Table 11.

The cost analysis of subbase constructed by pond ash, pond ash mixed with admixtures and conventional subbase material is shown in Table 12. The details of cost are worked out assuming the plant output per day is $300 \mathrm{~m}^{3}$. The calculations of admixtures are done as below:

$$
\begin{array}{ll}
\text { Density of polypropylene fibre } & =920 \mathrm{~kg} / \mathrm{m}^{3} \\
\text { Density of lime } & =3350 \mathrm{~kg} / \mathrm{m}^{3} \\
\text { The amount of fibre required for the pond ash-fibre mix } & =(300 \times 0.5 \% \times 920 / 1000) \\
& =1.38 \mathrm{~T} \\
\text { The amount of lime required for the pond ash-lime mix } & =(300 \times 2 \% \times 3350 / 1000) \\
& =20.1 \mathrm{~T}
\end{array}
$$

The details of the cost analysis per $\mathrm{m}^{3}$ for base course [water bound macadam (WBM) of Grade-3] are shown in Table 13 on a similar basis.

The cost analysis of dense bituminous macadam (DBM) as per Ministry of Road Transport \& Highways (MORT\&H), Government of India -Grade-2 is shown in Table 14, using the same approach. The compositions of the adopted DBM materials are considered as per Sinha (2009):

$$
\text { Coarse aggregate }(\mathrm{CA}) \quad=65 \%
$$


Fine aggregate (FA)

Bitumen content of mix

Bulk density of mix

The unit wt. of CA

The unit wt. of FA

$$
\begin{aligned}
& =35 \% \\
& =4.5 \% \text { by wt. } \\
& =2352 \mathrm{~kg} / \mathrm{m}^{3} \\
& =1545 \mathrm{~kg} / \mathrm{m}^{3} \\
& =1650 \mathrm{~kg} / \mathrm{m}^{3}
\end{aligned}
$$

The details of cost are worked out assuming the plant output per day $=147 \mathrm{MT}\left(62.5 \mathrm{~m}^{3}\right)$

Finally, the cost analysis of bituminous concrete (BC) is shown in Table 15. The adopted BC materials are as per MORT\&H, with the following composition (Sinha, 2009):

$\begin{array}{ll}\text { Coarse aggregate (CA) } & =62 \% \\ \text { Fine aggregate (FA) } & =35 \% \\ \text { Filler (lime) } & =3 \% \\ \text { Bitumen content of mix } & =5.5 \% \text { by wt. } \\ \text { Bulk density of mix } & =2376 \mathrm{~kg} / \mathrm{m}^{3} \\ \text { The unit wt. of CA } & =1545 \mathrm{~kg} / \mathrm{m}^{3} \\ \text { The unit wt. of FA } & =1650 \mathrm{~kg} / \mathrm{m}^{3}\end{array}$

The details of cost are worked out assuming the plant output per day $=147 \mathrm{MT}\left(61.9 \mathrm{~m}^{3}\right)$

The cost analysis per $\mathrm{m}^{3}$ for subgrade, subbase, WBM, DBM and BC are summarized in Table 16. The construction cost of different layers including the subbase layers consisting of pond ash alone and the pond ash stabilized with two different admixtures for the same service life is given in Table 17 for a $1 \mathrm{~km}$ long pavement (using the results summarized earlier in the "subbase thickness" column of Table 10). Percentage savings in total cost by direct replacement of conventional subbase material by pond ash alone and of ash mixes with admixtures are also shown in Table 17. 
As mentioned earlier, for the same pavement life an increased thickness of sub-base made of ash-based material could be used to partially replace a thickness of WBM. A comparison of the savings in cost of construction with respect to thickness ratio of WBM to subbase for various subbase materials considering maximum vertical compressive strain at the top of subgrade and maximum tensile strain at the bottom of DBM is shown in Fig. 9 and Fig. 10, respectively. This is based on the thickness data presented in the subbase and WBM thickness columns of Table 10 and on similar computations for other thickness combinations.

From Fig. 9, the saving in total cost of construction is $11.49 \%, 5.18 \%$ and $12.41 \%$ when 200 $\mathrm{mm}$ thick subbase layer is made up of pond ash with no addition, $0.5 \%$ fibre and $2 \%$ lime, respectively, keeping the WBM thickness at $250 \mathrm{~mm}$ (thickness ratio $=1.25$ ). The saving in total cost of construction is $12.13 \%, 5.54 \%$ and $12.69 \%$ when $200 \mathrm{~mm}$ subbase layer is made up of the same materials as mentioned above, keeping the WBM thickness as $200 \mathrm{~mm}$ (thickness ratio $=1.0$ ); and savings of $12.39 \%, 5.68 \%$ and $12.97 \%$ are achieved for a $150 \mathrm{~mm}$ WBM thickness and a 200 mm subbase layer (thickness ratio $=0.75$ ).

The saving in total cost of construction for the equivalent thicknesses of subbase layer made up of pond ash alone and with $2 \%$ lime, considering tensile strain at the bottom of DBM, could not be made. This is because, instead of a saving, the cost of construction of the pavement is increased due to application of these materials (due to cost of subbase preparation being greater than for the saving in subbase made up of conventional subbase material). Only $0.5 \%$ fibre treatment produces a cost saving when tensile strain at the bottom of the DBM layer is considered. Figure 10 shows the possible savings as a function of WBM and sub-base thickness.

The sensitivity of the percentage saving of cost of construction of $1 \mathrm{~km}$ pavement was checked based on a small parametric study considering maximum vertical compressive strain at the top of subgrade and maximum tensile strain at the bottom of DBM. In the study, the cost of WBM, DBM or BC course was (separately) increased by $10 \%$ from the basic price. The thickness ratio was 
varied by keeping WBM thickness $(=250 \mathrm{~mm})$ constant but increasing the subbase thickness from $200 \mathrm{~mm}$ to $500 \mathrm{~mm}$, as mentioned in Table 7.

For these $10 \%$ increases in material costs, the parametric study revealed that the saving in cost of construction reduced by $1.7-2.2 \%$ (pond ash alone), 3.1-4.0\% (ash $+5 \%$ fibre) and $1.3-1.6 \%$ (ash $+2 \%$ lime); the range being a consequence of the particular material that was $10 \%$ more expensive. These figures are based on the change in pavement performance as predicted by the change in vertical compressive strain. The predicted cost saving reduced a little less (by only 1.4$3.9 \%$ for the ash $+5 \%$ fibre) when the change in tensile strain at the bottom of the DBM was considered. Thus rutting is expected to be the controlling factor in determining sensitivity to material prices.

\section{DESIGN RECOMMENDATIONS}

From Fig. 9, for the thickness ratio of 0.3 (thickness of $\mathrm{WBM}=150 \mathrm{~mm}$ and subbase $=500$ $\mathrm{mm}$ ) considering vertical strain at the top of subgrade, the percentage saving of cost of construction of $1 \mathrm{~km}$ pavement is maximum $(=21.00 \%)$ when pond ash mixed with $0.5 \%$ fibre is used as subbase material. Similarly, for the thickness ratio of 1.25 (thickness of $\mathrm{WBM}=250 \mathrm{~mm}$ and subbase $=200$ $\mathrm{mm})$, the percentage saving of cost of construction of $1 \mathrm{~km}$ pavement is minimum $(=3.82 \%)$ when pond ash mixed with $2 \%$ lime is used as subbase material. As per IRC: 37-2001, considering a traffic load of 100 msa and CBR of $9 \%$ subgrade, the recommended thicknesses of WBM and subbase are $250 \mathrm{~mm}$ and 200 respectively (Fig. 1) i.e. thickness ratio $=1.25$. For this recommended thickness ratio, the percentage savings of cost of construction of pavement are minimum than the rest when subbase layer is made up of pond ash alone and mixed with admixtures. However, if we consider the above recommended thicknesses of WBM and subbase as per IRC: 37-2001, the service 
life ratio of the pavement will be reduced by $18 \%$ ( $\mathrm{SLR}=0.82$ ) taking $\mathrm{SLR}=1.00$ for conventional subbase material (CSM).

Similarly, from Fig. 10, for the thickness ratio of 0.3 (thickness of WBM $=150 \mathrm{~mm}$ and subbase $=500 \mathrm{~mm}$ ) considering tensile strain at the top of WBM, the percentage saving of cost of construction of $1 \mathrm{~km}$ pavement is maximum $(=26.23 \%)$ when pond ash mixed with $0.5 \%$ fibre is used as subbase material. Similarly, for the thickness ratio of 1.25 (thickness of WBM $=250 \mathrm{~mm}$ and subbase $=200 \mathrm{~mm}$ ), the percentage saving of cost of construction of $1 \mathrm{~km}$ pavement is minimum $(=11.89 \%)$ when same material is used as subbase material.

The main purpose/ aim of the present study are to maximize the utilization of pond ash as subbase material alone or with admixture to replace the conventional subbase material, without affecting the service life of the pavement. Again while selecting the subbase material the cost of construction of the pavement is also to be considered. So keeping both the points in mind and considering Fig. 9 and Fig. 10, the thickness ratio of 0.3 (thickness of WBM $=150 \mathrm{~mm}$ and subbase $=500 \mathrm{~mm}$ ) when pond ash mixed with $0.5 \%$ fibre is used as subbase material is recommended for the construction of pavement keeping other course of pavement section constant.

\section{CONCLUSIONS}

In the present study, induced vertical strain and tensile strain at the top of subgrade and at the top of WBM, respectively, are used to compare quality and cost of different pavements when the subbase layer is made up of Badarpur pond ash alone and Badarpur pond ash stabilized with different admixtures. A commercially available finite element based software 'PLAXIS' is used to evaluate the vertical and tensile strain at the top of subgrade and at the top of WBM, respectively, and as well as the distribution of strain inside different layers of pavement. The pavement section was modelled as an axi-symmetric problem and standard boundary conditions were used. The extent of the boundaries of the section was then fixed by a small parametric study. 
A nominal pavement structure used for the parametric study was first designed as per IRC: 37-2001 considering a traffic load of $100 \mathrm{msa}$ and CBR of $9 \%$ corresponding to Delhi silt subgrade at Jamia Milia Islamia. The thickness of subbase layer, water bound macadam (WBM) layer and dense bituminous macadam (DBM) layer was then varied with respect to this nominal pavement and the response of the pavement was evaluated.

Designed life and service life of a pavement is defined as the cumulative number of standard axles that can be carried before strengthening of pavement is necessary based on rutting failure criterion. A standard equation is available that uses maximum subgrade vertical strain to evaluate the design life and thus, the quality of the pavement. A service life ratio is defined as a function of induced subgrade strain in a given pavement vis-à-vis in a conventional pavement structure. Thus, the service life ratio indicates the lifetime of other pavements vis-à-vis conventional pavement structure.

An equivalent thickness is defined as the modified thickness of a particular layer of a new pavement required that has one of the layers made up of new material such that the lifetime of the new pavement remains the same as that of the conventional pavement. Based on the above parametric study, the equivalent thickness of subbase, water bound macadam (WBM) and dense bituminous macadam (DBM) layers are calculated when the subbase layer is made up of Badarpur pond ash mixed with no additive, $0.5 \%$ fibre and $2 \%$ lime. This was followed by the cost analysis of $1 \mathrm{~km}$ long pavement structure with a top width of $3.75 \mathrm{~m}$ based on the schedule of rates for Delhi region. Based on this study, following conclusions are drawn.

1. The vertical compressive strain was found to be maximum for pond ash.

2. i) With the increase of percentage of fibre(upto 0.5\%), the stiffness of pavement increases and the maximum strain decreases. 
ii) With the increase of percentage of lime (upto 5\%), the stiffness of pavement increases and the maximum strain decreases. But from simplicity of mixing point of view, the percentage of lime used was $2 \%$ in the test.

3. For the same service life ratio (SLR), the thickness of subbase layer made up of conventional subbase material $(=200 \mathrm{~mm})$, varies from $0.145-0.315 \mathrm{~m}$. The maximum thickness is obtained from pond ash and minimum from fibre. The corresponding saving in total cost is $3.82 \%$ to $11.92 \%$. The maximum cost saving is in pond ash and minimum is in lime.

4. Keeping the subbase layer made of different admixtures constant $(=200 \mathrm{~mm})$, the same service life can be obtained by varying the thickness of WBM. Based on this, the thickness of WBM varies from 0.181-0.460 $\mathrm{m}$ for $200 \mathrm{~mm}$ thick subbase layer of different admixtures. The maximum WBM thickness was obtained where pond ash used as subbase material and minimum thickness was obtained where fibre reinforced pond ash used as subbase material. The saving in total cost of construction is $11.49 \%, 5.18 \%$ and $12.41 \%$ when $200 \mathrm{~mm}$ thick subbase layer is made up of pond ash with no addition, $0.5 \%$ fibre and $2 \%$ lime, respectively, considering WBM thickness as $250 \mathrm{~mm}$ (Thickness ratio $=1.25$ ). Again, the saving in total cost of construction is $12.13 \%, 5.54 \%$ and 12.69 and $12.39 \%, 5.68 \%$ and $12.97 \%$ when 200 mm subbase layer is made up of same materials as mentioned above, considering WBM thickness as $200 \mathrm{~mm}$ (Thickness ratio $=1.0$ ) and $150 \mathrm{~mm}$ (Thickness ratio $=0.75$ ), respectively.

5. Keeping the subbase layer made of different admixtures constant $(=200 \mathrm{~mm})$, the same service life can be obtained by varying the thickness of DBM. Based on this, the thickness of DBM varies from $0.108-0.200 \mathrm{~m}$ for $200 \mathrm{~mm}$ thick subbase layer of different admixtures. The maximum DBM thickness was obtained where pond ash was used as subbase material and minimum thickness was obtained where pond ash mixed with $0.5 \%$ fibre used as subbase material. 
7. Comparing subbase and WBM, the variation in subbase thickness give the maximum saving for same service life ratio.

8. Based on a parametric study, it is seen that the percentage saving of cost of construction of the pavement is between 1.3 and $4 \%$ for a $10 \%$ increase in WBM, DBM or BC costs.

\section{ACKNOWLEDGEMENTS}

The first author wishes to thank M/s PDP Steels Limited, Assam for funding and Delhi Technological University for allowing a short sabbatical visit to the University of Nottingham where most of the research reported here was performed. Both authors thank the Nottingham Transportation Engineering Centre at the University of Nottingham for providing the facilities to host this visit.

\section{REFERENCES}

Ahmed, A.T. and Khalid, H.A. (2008), "Characterizing the resilient behaviour of treated municipal solid waste bottom ash blends for use in foundations", Advances in Transportation Geotechnics, Eds.- Ellis, Yu, McDowell, Dawson \& Thom, Taylor \& Francis Group, London, pp. 59-64

Atkinson, V.M., Chaddock, B.C. \& Dawson, A.R.(1999), "Enabling the use of secondary aggregates and binders in pavement foundations", TRL Report 408, Transport Research Laboratory, Crowthorne, UK, 31pp.

Bauer, G.E., and Fatani, M.N. (1991), "Strength characteristics of sand reinforced with rigid and flexible elements", Proc., IX Asian Regional Conf. on Soil Mechanics and Foundation Engg., Bangkok,1, pp. 471-474

Blodgett, S. (2004), "Environmental impacts of aggregate and stone mining - New Mexico case study”, Center for Science in Public Participation, USA

Central Road Research Institute (2009), "Pavement engineering and materials - pavement evaluation", Annual Report 2009-10, pp. 51-76

Chakraborty, T.K., and Dasgupta, S.P. (1996), "Randomly reinforced fly ash foundation material", Indian Geotechnical Conf., Madras, India, 1, pp. 231-235 
Chakroborty, P. and Das, (2003), "Principles of transportation engineering", Prentice Hall of India, New Delhi

Chand, S.K, and Subbarao, C. (2007), "Strength and slake durability of lime stabilized pond ash", J. Materials in Civil Engineering, ASCE, pp. 601-609

Chu, T. Y., Davidson, D. T., Goecker, W. L. and Moh, Z. C. (1995), "Soil stabilization with lime-fly ash mixtures: preliminary studies with silty and clayey soils", Highway Research Board Bulletin 108, pp. 102-112

Consoli, N.C., Prietto, P.D.M., and Ulbrich, L.A. (1998), "Influence of fibre and cement addition on behaviour of sandy soil”, J. Geotech. and Geoenvir. Engg., ASCE, 124 (12), pp. 1211-1214

Dawson, A.R. and Bullen, F. (1991), "Furnace Bottom ash: its engineering properties and its use as a sub-base material”, Proc., Institution of Civil Engineers, Part 1, pp. 993-1009

Dawson, A.R., Cheema, J.A., Nunes, M.C.M., Chaddock, B.C.J. and Atkinson, V. (1996), "Enabling the use of secondary aggregates and binders in pavement foundations", Results of Phase 2 Study, Link II Project, University of Nottingham, UK

DiGioia, A. M. and Nuzzo, W. L. (1972), "Fly ash as structural fill”, Journal of Power Div., ASCE, vol. 98 (1), pp. 77-92

Fawconnier, C.J. and Korsten, R.W.O. (1982), “Ash fill in pillar design- Increased Underground Extraction of Coal”, The SAIMM Monograph Series 4, pp. $277-361$

Gopalan, M.K. and Haque, M.N. (1986), "Strength development of clinically cured plain fly ash concretes", in Proceed. of Aus. Road Research Board, Vol 13, Pt. 5, pp 27-33

Gray, D.H., Tons, E. and Thiruvengadam, T.R. (1994), "Performance evaluation of a cementstabilized fly ash base", Transportation Research Record, 1440, pp. 51-59

Gulhati, S.K. and Datta, M. (1999), “Geotechnical engineering”, Tata McGraw-Hill, New Delhi Huang, Y.H. (1993), “Pavement analysis and design”, Prentice-Hall, Englewood Cliffs, New York.

IRC:37, (2001), "Guidelines for the design of flexible pavement", Indian Roads Congress, , New Delhi

IRC:86, (1983), "Geometric design standards for urban roads in plains", Indian Roads Congress, , New Delhi

Joshi, R.C., Natt, G.S. and Wright, P.J. (1981), "Soil improvement by lime-fly ash slurry injection", in Proc. 10th Int. Conference on Soil Mechanics \& Foundation Engg., Stockholm, vol. 3, pp. 707712

Kaniraj, S.R., and Havanagi, V.G. (2001), "Behaviour of cement stabilized fibre-reinforced fly ashsoil mixture”, J. Geotech. And Geoenvir.Engg., ASCE, 127 (7), pp. 574-584 
Kumar, R., Kanaujia, V.K. and Chandra, D. (1996), "Engineering behaviour of fibre-reinforced pond ash and silty sand", J. Geosynthetics Internationals 1999, Vol. 6, No. 6, pp. 509-518

Kumar, P. and Singh, S.P. (2008), "Fibre-reinforced fly ash sub bases in rural roads", J. Transportation Engg., ASCE, 134, pp. 171-180

Ksaibati, K. and Conklin, T.L. (1994), "Field performance evaluation of cement-treated bases with and without fly ash", Transportation Research Record, 1440, pp. 16-21

Ksaibati, K and Bowen, M.M. (2001), "Utilization of bottom ash in pavement bases", Proc., Beneficial Use of Recycled Materials in Transportation Applications, Edi. T. T. Eighmy, Nov. 1315, Arlington, Virginia, pp. 875-884

Lee, K.W., Huston, M.T., Davis, J. and Vajjhalla, S. (2001), "Structural analysis of New England subbase materials and structures", Report of Project No. 94-1 (NETCR 26), The New England Transportation Consortium

Lee, S.W. and Fishman, K.L. (1993), "Resilient and plastic behavior of classifier tailings and fly ash mixtures", Transportation Research Record, 1418, pp. 8-15

Loulizi, A., Flintsch, G.W., Al-Qadi, I.L. and Mokarem, D. (2006), "Comparing resilient modulus and dynamic modulus of hot-mix asphalt as material properties for flexible pavement design", Transportation Research Record: Journal of the Transportation Research Board of the National Academies, Washington, D.C., pp. 161-170

Maser, K.R., R.E. Wallhagen and Dieckman, J. (1975), "Development of fly ash cement mine sealing system", USBM, Open File Report 26-76, NTIS -PB-250611

Michalowski, R.L., and Zhao, A. (1996), "Failure of fibre reinforced granular soils", J. Geotech. Engg., Div., ASCE, 122 (3), pp. 226-234

Mishra, M.K., and Karanam, U.M. (2006), "Geotechnical characterization of fly ash composites for backfilling mine voids", J., Geotechnical and Geological Engineering, Vol.24 (6), 1749-1765

MORT\&H (2011), "Report of the working group on central roads sector, 12th Five Year Plan (2012-17)”, Ministry of Road Transport \& Highways, Government of India

Nataraj, M.S., and McManis, K.L. (1997), "Strength and deformation properties of soils reinforced with fibrillated fibres", Geosynthetics Int., 4 (1), 65-79, 1997

Nunes, M.C.M. (1997), "Enabling the use of alternative materials in road construction", PhD Thesis, University of Nottingham, UK

Ornebjerg, H, Franck, J, Lamers, F., Angotti, F., Morin, R. and Brunner, M. (2006), "Management of bottom ash from WTE plants - an overview of management options and treatment methods", Report of Working Group on Thermal Treatment of Waste, International Solid Waste Association 
Palariski, J. (1993), "The use of fly ash tailings, rock and binding agents as consolidated backfill for coal mines", Proceed. of Mine fill 1993, Edi. H.W. Gelen, SAIMM, pp 403 - 408

Raymond, S. (1961), "Pulverized fuel ash as embankment material", In Proc., of The Institution of Civil Engineers, Vol. 19, 515-536

Sarkar, R., Abbas, S. M, and Shahu, J. T. (2012), "A comparative study of geotechnical behaviour of lime stabilized pond ashes from Delhi region", International Journal of GEOMATE, Vol. 03, No 01, pp. 273-279

Santoni, R.L., and Webster, S.L. (2001), "Airfields and road construction using fibre stabilization of sands”, J. Transportation Engg., ASCE, 127 (2), pp. 96-104

Setty, K.R.N.S., and Rao, S.V.G. (1987), "Characteristics of fibre reinforced lateritic soils", Indian Geotech. Conf., Banglore, India, 1, pp. 329-333

Sherwood, P. (1995), "Alternative materials in road construction", Publisher - Thomas Telford Publishing, London, UK

Shewbridge, S.E., and Sitar, N. (1989), "Deformation characteristics of reinforced soil in direct shear”, J. Geotech. Engg., Div., ASCE, 115 (8), pp. 1134-1147

Shodhganga (2006) , "Engineering properties of subgrade soils, moorum and aggregate", http://shodhganga.inflibnet.ac.in/bitstream/10603/8702/12/12_chapter\%204.pdf

Singh, S.P., and Kumar, P. (2005), "Utilization of fibre reinforced flyash in road sub-bases", Fly Ash Utilization Programme (FAUP), TIFAC, DST, New Delhi, VIII 17.1-17.8

Singh, S.P., and Ramaswamy, S.V. (2005), "Utilization potential of cement stabilized flyash-gbfs mixes in highway construction", Fly Ash Utilization Programme (FAUP), TIFAC, DST, New Delhi, VIII 4.29-14.11

Sinha, A.K. (2009), "Study on subbase materials for rural roads", PhD Thesis, Dept. of Civil Engineering, IIT-Roorkee

Subbarao, C., Ghosh, A., Behera, L., Mukherjee, S. and Chand, S.K., (2001), "Fly ash and stabilized fly ash as construction materials", Proc., International Conference on Advances in Civil Engineering, pp. 1085-1092

Theyse, H.L. (2002), "Stiffness, strength, and performance of unbound aggregate material: application of South African HVS and laboratory results to California flexible pavements", Report California Partnered Pavement Research Program, University of California

Titi, H.H., Coenen, A.R. and Elias, M.B. (2009), "Resilient characteristics of bottom ash", Bearing Capacity of Roads, Railways and Airfields, Eds.- Tutumluer and Al-Qadi, Taylor \& Francis Group, London, ISBN 978-0415-87199-0, pp. 117-124

Tirumala, K.G. (2007), "Geotechnical characteristics of pond ash mixed with randomly oriented Fibres”, M. Tech Thesis, Dept. of Civil Engineering, IIT-Delhi 
Table 1 Chemical properties of Badarpur pond ash

\begin{tabular}{|l|l|}
\hline Constituents in Percentage & Badarpur Pond ash \\
\hline $\mathrm{SiO}_{2}$ & 49.5 \\
\hline $\mathrm{Al}_{2} \mathrm{O}_{3}$ & 25.01 \\
\hline $\mathrm{MgO}$ & 1.21 \\
\hline $\mathrm{Fe}_{2} \mathrm{O}_{3}$ & 9.81 \\
\hline $\mathrm{CaO}$ & 4.48 \\
\hline Loss on Ignition & 9.79 \\
\hline Others & 0.08 \\
\hline
\end{tabular}

Table 2 Geotechnical properties of Badarpur pond ash

\begin{tabular}{|l|l|}
\hline Properties & Badarpur Pond ash \\
\hline Fine sand size, $0.475-0.075 \mathrm{~mm}, \%$ & 72 \\
\hline Silt size, $0.075-0.002 \mathrm{~mm}, \%$ & 22 \\
\hline Uniformity coefficient, $\mathrm{C}_{\mathrm{u}}$ & 4.8 \\
\hline Coefficient of curvature, $\mathrm{C}_{\mathrm{c}}$ & 1.05 \\
\hline Effective size $\mathrm{D}_{10}, \mathrm{~mm}$ & 0.049 \\
\hline $\mathrm{D}_{30}$ size, $\mathrm{mm}$ & 0.11 \\
\hline $\mathrm{D}_{60}$ size, $\mathrm{mm}$ & 0.235 \\
\hline Specific gravity & 2.1 \\
\hline LL and PL & Non-plastic \\
\hline Maximum dry unit weight, $\mathrm{kN} / \mathrm{m}^{3}$ & 11.7 \\
\hline Optimum moisture content, \% & 32 \\
\hline Triaxial $(\mathrm{CD})$ Test & 0 \\
\hline Cohesion intercept (c'), $\mathrm{kPa}$ & 28.9 \\
\hline Angle of shearing resistance $\Phi^{\prime},{ }^{\circ}$ & \\
\hline
\end{tabular}

Table 3 Physical and engineering properties of polypropylene fibres (supplier's data) Properties Value 


\begin{tabular}{|l|l|}
\hline Molecular formula & $\left(\mathrm{CH}_{2}-\mathrm{CH}_{2}\right)_{\mathrm{n}}$ \\
\hline Young's modulus $\mathrm{GN} / \mathrm{m}^{2}$ & 7.1 \\
\hline Melting point, ${ }^{\circ} \mathrm{C}$ & 89 \\
\hline Tensile strength, $\mathrm{N} / \mathrm{mm}^{2}$ & 125.28 \\
\hline Unit weight, $\mathrm{kN} / \mathrm{m}^{3}$ & 9.2 \\
\hline Diameter $(\mathrm{mm})$ & 0.3 \\
\hline Aspect Ratio & 90 \\
\hline
\end{tabular}

Table 4 Chemical Composition of Lime (supplier's data)

\begin{tabular}{|l|l|}
\hline Minimum Array (Acidimetric) & $95.00 \%$ \\
\hline \multicolumn{2}{|l|}{ Maximum Limits of Impurities } \\
\hline Chloride $(\mathrm{Cl})$ & $0.10 \%$ \\
\hline Sulphate $\left(\mathrm{SO}_{4}\right)$ & $0.50 \%$ \\
\hline Iron $(\mathrm{Fe})$ & $0.10 \%$ \\
\hline Lead $(\mathrm{Pb})$ & $0.02 \%$ \\
\hline Loss on Ignition & $10 \%$ \\
\hline
\end{tabular}

Table 5 Experimental program

\begin{tabular}{|l|l|}
\hline Source of Pond ash & Details of experiments \\
\hline \multirow{5}{*}{ Badarpur } & Specific gravity \\
\cline { 2 - 2 } & Grain size distribution \\
\cline { 2 - 2 } & Atterberg limit tests \\
\cline { 2 - 3 } & $\begin{array}{l}\text { Compaction tests: } \\
\text { Light compaction (standard Proctor) test and heavy } \\
\text { compaction (modified Proctor) test }\end{array}$ \\
\cline { 2 - 2 } & $\begin{array}{l}\text { Consolidated drained triaxial tests under confining pressures of } \\
100,200, \text { and } 300 \mathrm{kPa}\end{array}$ \\
\hline
\end{tabular}

Table 6 Standard codes used to perform laboratory tests

\begin{tabular}{|l|l|}
\hline Laboratory tests & Standard/Procedures \\
\hline Specific gravity & RILEM recommendations (1989) \\
\hline Grain size analysis & IS: 2720 ( Part 4) - 1985 \\
\hline
\end{tabular}




\begin{tabular}{|l|l|}
\hline Atterberg limit test & IS: 2720 ( Part 5) - 1985 \\
\hline Standard Proctor compaction test & IS: 2720 ( Part 7) - 1980 \\
\hline Modified Proctor compaction test & IS: 2720 ( Part 8) - 1983 \\
\hline Consolidated drained triaxial shear test & IS: $2720($ Part 19) - 1981 \\
\hline
\end{tabular}

Table 7 Values of modulus of elasticity, Poisson's ratio and shear parameters for different pavement materials

\begin{tabular}{|c|c|c|c|c|c|c|c|c|}
\hline$\underset{\Xi}{\grave{\Xi}}$ & 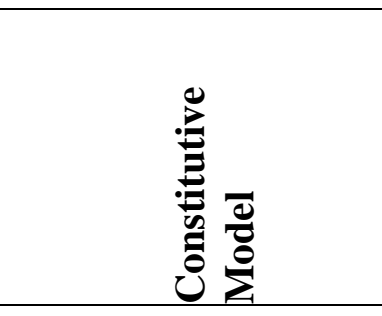 & 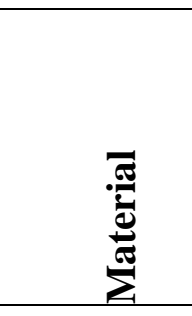 & 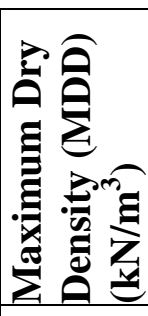 & 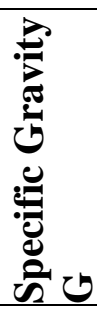 & 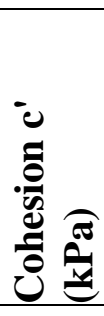 & 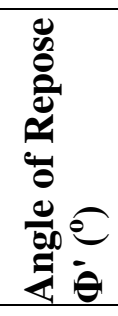 & 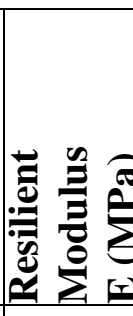 & 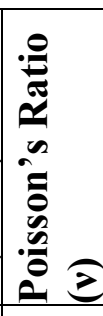 \\
\hline $\mathrm{BC}$ & Elastic & Bitumen & 21 & & & & 700 & 0.35 \\
\hline $\mathrm{DBM}$ & Elastic & $\begin{array}{l}\text { Bitumen } \\
\text { Mix }\end{array}$ & 18 & 2.3 & - & - & 1400 & 0.35 \\
\hline WBM & $\begin{array}{l}\text { Elasto-plastic (Mohr- } \\
\text { Coulomb) }\end{array}$ & $\begin{array}{l}\text { Graded } \\
\text { Aggregate }\end{array}$ & 17.6 & 2.25 & 40 & 45 & 110 & 0.35 \\
\hline \multirow{11}{*}{$\begin{array}{l}0 \\
0 \\
\tilde{E} \\
0 \\
0 \\
0\end{array}$} & \multirow{11}{*}{$\begin{array}{l}\text { Elasto-plastic (Mohr- } \\
\text { Coulomb) }\end{array}$} & $\mathrm{CSM}^{*}$ & 20.4 & 2.67 & 14 & 37 & 140 & \multirow{11}{*}{0.35} \\
\hline & & $\mathrm{PA}^{* *}$ & 11.7 & 2.1 & 0 & 28.9 & 70 & \\
\hline & & \multicolumn{6}{|l|}{ PA + Fibre } & \\
\hline & & $0.2 \%$ & 11.8 & 2.11 & 18 & 30.3 & 100 & \\
\hline & & $0.3 \%$ & 11.9 & 2.22 & 21.4 & 31.6 & 140 & \\
\hline & & $0.4 \%$ & 12 & 2.25 & 24.8 & 33 & 160 & \\
\hline & & $0.5 \%$ & 12 & 2.26 & 26.9 & 34 & 170 & \\
\hline & & \multicolumn{6}{|l|}{ PA + Lime } & \\
\hline & & $2 \%$ & 12.8 & 2.22 & 14 & 31.5 & 80 & \\
\hline & & $3 \%$ & 13.5 & 2.25 & 20 & 32.2 & 110 & \\
\hline & & $5 \%$ & 13.9 & 2.31 & 23.4 & 33.2 & 135 & \\
\hline Subgrade & $\begin{array}{l}\text { Elasto-plastic (Mohr- } \\
\text { Coulomb) }\end{array}$ & Delhi Silt & 18 & 2.64 & 20 & 30 & 70 & 0.35 \\
\hline
\end{tabular}

*Conventional Subbase Material ** Pond Ash

Table 8 Variation in thickness considered in pavement study

\begin{tabular}{|l|l|l|}
\hline Layer & $\begin{array}{l}\text { Reference pavement } \\
\text { thickness }(\mathbf{m m})\end{array}$ & Variation in thickness (mm) \\
\hline Bituminous concrete (BC) & 50 & None \\
\hline $\begin{array}{l}\text { Dense Bituminous Macadam } \\
\text { (DBM) }\end{array}$ & 135 & $110,135,160,185$ \\
\hline Base Course (WBM) & 250 & $150,200,250$ \\
\hline
\end{tabular}




\begin{tabular}{|l|l|l|} 
Sub-base Course & 200 & $200,250,300,350,400,450,500$ \\
\hline Subgrade & 300 & None \\
\hline
\end{tabular}

Table 9 Service life ratio (SLR) considering vertical compressive strains (VCS) at the top of subgrade and tensile strain (TS) at the bottom of the DBM for different subbase materials (subbase thickness $=200 \mathrm{~mm}, \mathrm{WBM}=250 \mathrm{~mm}$ )

\begin{tabular}{|l|l|l|l|l|}
\hline & Pond Ash (PA) & $\begin{array}{l}\text { PA + Fibre } \\
(\mathbf{0 . 5 \%})\end{array}$ & $\begin{array}{l}\text { PA + Lime } \\
\mathbf{( 2 . 0 \% )}\end{array}$ & CSM \\
\hline VCS (x 10 $\left.{ }^{-3} \%\right)$ & 230 & 160 & 190 & 182 \\
\hline SLR (VCS) & 0.35 & 1.79 & 0.82 & 1.00 \\
\hline TS (x 10 $\left.0^{-3} \%\right)$ & 115 & 82 & 99 & 92 \\
\hline SLR (TS) & 0.42 & 1.56 & 0.75 & 1.00 \\
\hline
\end{tabular}

Table 10 Variation in equivalent thicknesses of different subbase materials for the same life of pavement

\begin{tabular}{|l|c|c|c|c|c|c|}
\hline \multirow{2}{*}{ Material } & \multicolumn{2}{|c|}{ Subbase } & \multicolumn{2}{c|}{ WBM } & \multicolumn{2}{c|}{ DBM } \\
\cline { 2 - 7 } & $\begin{array}{l}\text { Required } \\
\text { thickness } \\
(\mathbf{m m})\end{array}$ & $\begin{array}{l}\text { Increase in } \\
\text { thickness } \\
(\%)\end{array}$ & $\begin{array}{l}\text { Required } \\
\text { thickness } \\
(\mathbf{m m})\end{array}$ & $\begin{array}{l}\text { Increase in } \\
\text { thickness } \\
(\%)\end{array}$ & $\begin{array}{l}\text { Required } \\
\text { thickness } \\
(\mathbf{m m})\end{array}$ & $\begin{array}{l}\text { Increase in } \\
\text { thickness } \\
(\%)\end{array}$ \\
\hline CSM as per IRC (2001) & 200 & 0 & 250 & 0 & 135 & 0 \\
\hline Pond Ash + Fibre (0.5\%) & 95 & -52.5 & 150 & -40.0 & 97 & -28.2 \\
\hline Pond Ash + Lime (2.0\%) & 300 & 50.0 & 352 & 40.8 & 169 & 25.2 \\
\hline Pond Ash alone & 580 & 190 & 463 & 85.2 & 210 & 55.6 \\
\hline
\end{tabular}

Table 11 Cost analysis of subgrade course

\begin{tabular}{|l|l|l|l|l|l|l|}
\hline \multicolumn{9}{|l|}{ Taking Output: $100 \mathrm{~m}^{3}$} \\
\hline (a) & Labour Component \\
\hline & $\begin{array}{l}\text { Sl. } \\
\text { No. }\end{array}$ & Item & Unit & Quantity & Rate (Rs.) & $\begin{array}{l}\text { Amount } \\
\text { (Rs.) }\end{array}$ \\
\hline & 1 & Mate & Day & 0.04 & 360.49 & 14.42 \\
\hline & 2 & Labour (Unskilled) & Day & 1.50 & 238.07 & 357.11 \\
\hline & Total & & & 371.53 \\
\hline & Total per $\mathrm{m}^{3}$ & & \\
\hline (b) & Machinery & & & \\
\hline
\end{tabular}




\begin{tabular}{|l|l|l|l|l|l|l|} 
& $\begin{array}{l}\text { Sl. } \\
\text { No. }\end{array}$ & Item & Unit & Quantity & Rate (Rs.) & $\begin{array}{l}\text { Amount } \\
\text { (Rs.) }\end{array}$ \\
\hline 1 & Grader & $\mathrm{Hr}$ & 2.00 & 1800.00 & 3600.00 \\
\hline & 2 & Dozer & $\mathrm{Hr}$ & 0.50 & 1200.00 & 600.00 \\
\hline 3 & Water Tanker & $\mathrm{Hr}$ & 5.00 & 350.00 & 1750.00 \\
\hline 4 & Vibratory Compactor & $\mathrm{Hr}$ & 1.25 & 760.00 & 950.00 \\
\hline & 5 & Dumper & $\mathrm{Hr}$ & 1.25 & 1400.00 & 1750.00 \\
\hline & 6 & Excavator & $\mathrm{Hr}$ & 1.00 & 1700.00 & 1700.00 \\
\hline & Soil Spreading Unit & $\mathrm{Hr}$ & 0.36 & 2250.00 & 810.00 \\
\hline & \multicolumn{5}{l}{} & \\
\hline
\end{tabular}

Table 12 Cost analysis of subbase constructed by pond ash, pond ash mixed with admixtures and conventional subbase material

Taking Output: $300 \mathrm{~m}^{3}$

\begin{tabular}{|l|l|l|l|l|l|l|}
\hline (a) & Labour Component \\
\hline & Sl. No. & Item & Unit & Quantity & Rate (Rs.) & $\begin{array}{l}\text { Amount } \\
\text { (Rs.) }\end{array}$ \\
\hline & 1 & Mate & Day & 0.48 & 360.49 & 173.04 \\
\hline 2 & Labour (Skilled) & Day & 2.00 & 292.45 & 584.90 \\
\hline 3 & Labour (Unskilled) & Day & 10.00 & 238.07 & 2380.70 \\
\hline & Total & & & 3138.64 \\
\hline
\end{tabular}




\begin{tabular}{|c|c|c|c|c|c|c|c|}
\hline \multirow[t]{2}{*}{ (b) } & \multicolumn{7}{|c|}{ Machinery } \\
\hline & S1. No. & \multicolumn{2}{|l|}{ Item } & Unit & Quantity & Rate (Rs.) & $\begin{array}{l}\text { Amount } \\
\text { (Rs.) }\end{array}$ \\
\hline & 1 & \multicolumn{2}{|l|}{ Grader } & $\mathrm{Hr}$ & 6.00 & 1800.00 & $\begin{array}{l}10800.0 \\
0\end{array}$ \\
\hline & 2 & \multicolumn{2}{|l|}{ Water Tanker } & $\mathrm{Hr}$ & 5.00 & 350.00 & 1750.00 \\
\hline & 3 & \multicolumn{2}{|l|}{ Vibratory Compactor } & $\mathrm{Hr}$ & 10.00 & 760.00 & 7600.00 \\
\hline & 4 & \multicolumn{2}{|l|}{ Tractor with Rotavator } & $\mathrm{Hr}$ & 10.00 & 360.00 & 3600.00 \\
\hline & \multicolumn{6}{|l|}{ Total } & $\begin{array}{l}23750.0 \\
0\end{array}$ \\
\hline & \multicolumn{6}{|c|}{ Total per $\mathrm{m}^{3}$} & 79.17 \\
\hline (c) & \multicolumn{7}{|c|}{ Material Cost } \\
\hline & S1. No. & \multicolumn{2}{|l|}{ Item } & Unit & Quantity & $\begin{array}{l}\text { Rate } \\
\text { (Rs.) }\end{array}$ & $\begin{array}{l}\text { Amount } \\
\text { (Rs.) }\end{array}$ \\
\hline & 1 & \multicolumn{2}{|c|}{ Pond Ash ( $30 \%$ extra for loose state) } & $\mathrm{m}^{3}$ & 390.00 & 0.00 & 0.00 \\
\hline & 2 & \multicolumn{2}{|c|}{ Fibre $(0.5 \%)$} & $\mathrm{T}$ & 1.38 & 96000.00 & $\begin{array}{l}132480.0 \\
0\end{array}$ \\
\hline & 3 & \multicolumn{2}{|l|}{ Lime $(2 \%)$} & $\mathrm{T}$ & 20.1 & 7000.00 & $\begin{array}{l}140700.0 \\
0\end{array}$ \\
\hline & 4 & \multicolumn{2}{|l|}{$\mathrm{CSM}^{*}$} & $\mathrm{~m}^{3}$ & 384.00 & 591.10 & $\begin{array}{l}226982.4 \\
0\end{array}$ \\
\hline & \multicolumn{2}{|c|}{ Combinations } & \multicolumn{2}{|c|}{$\begin{array}{l}1 \\
\text { (Rs.) }\end{array}$} & $\begin{array}{l}1+2 \\
\text { (Rs.) }\end{array}$ & $\begin{array}{l}1+3 \\
\text { (Rs.) }\end{array}$ & $\begin{array}{l}4 \\
\text { (Rs.) }\end{array}$ \\
\hline & \multicolumn{2}{|l|}{ Total } & \multicolumn{2}{|l|}{0.00} & 132480.00 & $\begin{array}{l}140700.0 \\
0\end{array}$ & $\begin{array}{l}226982.4 \\
0\end{array}$ \\
\hline & \multicolumn{2}{|c|}{ Total per $\mathrm{m}^{3}$} & \multicolumn{2}{|l|}{0.00} & 441.60 & 469.00 & 756.61 \\
\hline (d) & \multicolumn{2}{|c|}{$\mathrm{CP} \& \mathrm{OC}^{* *}$} & \multicolumn{2}{|c|}{11.20} & 66.40 & 69.83 & 105.78 \\
\hline & \multicolumn{2}{|c|}{ Grand Total $(a+b+c+d)$} & \multicolumn{2}{|c|}{100.83} & 597.63 & 628.46 & 952.02 \\
\hline
\end{tabular}

*Rate of CSM (75\% of RBM @ Rs. 572.20 and 25\% of 45-63 Stone Ballast @ Rs.647.80)

**Contractor's Profit and Overhead Charges @12.5\% on (a) + (b) + (c)

Table 13 Cost analysis of base course [water bound macadam (WBM) of Grade-3]

\begin{tabular}{|c|c|c|c|c|c|c|}
\hline \multicolumn{7}{|c|}{ Taking Output: $360 \mathrm{~m}^{3}$} \\
\hline \multirow[t]{7}{*}{ (a) } & \multicolumn{6}{|c|}{ Labour Component } \\
\hline & $\begin{array}{l}\text { Sl. } \\
\text { No. }\end{array}$ & Item & Unit & Quantity & Rate (Rs.) & Amount (Rs.) \\
\hline & 1 & Mate & Day & 10.08 & 360.49 & 3633.74 \\
\hline & 2 & Labour(Skilled) & Day & 2.00 & 292.45 & 584.90 \\
\hline & 3 & Labour(Unskilled) & Day & 200.00 & 238.07 & 47614.00 \\
\hline & \multicolumn{5}{|c|}{ Total } & 51832.64 \\
\hline & \multicolumn{5}{|c|}{ Total per ${ }^{\mathrm{m} 3}$} & 143.98 \\
\hline \multirow[t]{5}{*}{ (b) } & \multicolumn{6}{|c|}{ Machinery } \\
\hline & $\begin{array}{l}\text { Sl. } \\
\text { No. }\end{array}$ & Item & Unit & Quantity & Rate (Rs.) & Amount (Rs.) \\
\hline & 1 & Vibratory Compactor & $\mathrm{Hr}$ & 45.00 & 760.00 & 34200.00 \\
\hline & 2 & Water Tanker & $\mathrm{Hr}$ & 24.00 & 350.00 & 8400.00 \\
\hline & \multicolumn{5}{|c|}{ Total } & 42600.00 \\
\hline
\end{tabular}




\begin{tabular}{|c|c|c|c|c|c|c|}
\hline & \multicolumn{5}{|c|}{ Total per $\mathrm{m}^{3}$} & 118.33 \\
\hline \multirow[t]{5}{*}{ (c) } & \multicolumn{6}{|c|}{ Material Cost } \\
\hline & $\begin{array}{l}\text { Sl. } \\
\text { No. }\end{array}$ & Item & Unit & Quantity & Rate (Rs.) & Amount (Rs.) \\
\hline & 1 & GSB Material* & $\mathrm{m}^{3}$ & 522.00 & 659.64 & 344332.08 \\
\hline & \multicolumn{5}{|c|}{ Total } & 344332.08 \\
\hline & \multicolumn{5}{|c|}{ Total per $\mathrm{m}^{3}$} & 956.48 \\
\hline \multirow[t]{2}{*}{ (d) } & \multicolumn{5}{|c|}{ Contractor's Profit and Overhead Charges @ $12.5 \%$ on (a)+(b)+(c) } & 152.35 \\
\hline & \multicolumn{5}{|c|}{ Grand Total $(a+b+c+d)$} & 1371.14 \\
\hline
\end{tabular}

*Rate of GSB Material (80\% of 22-53 Stone Ballast @ Rs. 647.80 and 20\% of 10-12.5 Aggregate @ Rs.707.00)

Table 14 Cost analysis of dense bituminous macadam (DBM) of Grade-2

\begin{tabular}{|c|c|c|c|c|c|c|}
\hline \multicolumn{7}{|c|}{ Taking Output: $62.5 \mathrm{~m}^{3}$} \\
\hline \multirow[t]{5}{*}{ (a) } & \multicolumn{6}{|c|}{ Labour Component } \\
\hline & $\begin{array}{l}\text { S1. } \\
\text { No. }\end{array}$ & Item & Unit & Quantity & Rate (Rs.) & Amount(Rs.) \\
\hline & 1 & Labour(Unskilled) & Day & 16.50 & 238.07 & 3928.16 \\
\hline & \multicolumn{5}{|c|}{ Total } & 3928.16 \\
\hline & \multicolumn{5}{|c|}{ Total per $\mathrm{m}^{3}$} & 62.85 \\
\hline \multirow[t]{8}{*}{ (b) } & \multicolumn{6}{|c|}{ Machinery } \\
\hline & $\begin{array}{l}\text { Sl. } \\
\text { No. }\end{array}$ & Item & Unit & Quantity & Rate (Rs.) & Amount(Rs.) \\
\hline & 1 & Plant & Day & 1.00 & 10000.00 & 10000.00 \\
\hline & 2 & Tipper & Day & 3.60 & 1600.00 & 5760.00 \\
\hline & 3 & Loader & Day & 1.00 & 900.00 & 900.00 \\
\hline & 4 & Road Roller & Day & 3.60 & 1000.00 & 3600.00 \\
\hline & \multicolumn{5}{|c|}{ Total } & 20260.00 \\
\hline & \multicolumn{5}{|c|}{ Total per $\mathrm{m}^{3}$} & 324.16 \\
\hline \multirow[t]{2}{*}{ (c) } & \multicolumn{6}{|c|}{ Material Cost } \\
\hline & Sl. & Item & Unit & Quantity & Rate (Rs.) & Amount(Rs.) \\
\hline
\end{tabular}




\begin{tabular}{|l|l|l|l|l|l|l|} 
& No. & & & & & \\
\hline & 1 & Bitumen & $\mathrm{T}$ & 6.615 & 33000.00 & 218295.00 \\
\hline & 2 & Coarse Aggregate & $\mathrm{m}^{3}$ & 58.90 & 647.80 & 38155.42 \\
\hline & 3 & $\mathrm{~m}^{3}$ & 29.70 & 707.00 & 20997.90 \\
\hline & Fine Aggregate & & 277448.32 \\
\hline & \multicolumn{3}{l}{} & 4439.17 \\
\hline$(\mathrm{d})$ & \multicolumn{2}{|l|}{ Cotal per $\mathrm{m}^{3}$} & 603.27 \\
\hline & Grand Total $(\mathrm{a}+\mathrm{b}+\mathrm{c}+\mathrm{d})$ & 5429.45 \\
\hline
\end{tabular}

Table 15: Cost analysis of bituminous concrete (BC)

\begin{tabular}{|c|c|c|c|c|c|c|}
\hline \multicolumn{7}{|c|}{ Taking Output: $61.9 \mathrm{~m}^{3}$} \\
\hline \multirow[t]{2}{*}{ (a) } & \multicolumn{6}{|c|}{ Labour Component } \\
\hline & Sl. No. & Item & Unit & Quantity & Rate (Rs.) & $\begin{array}{l}\text { Amount } \\
\text { (Rs.) }\end{array}$ \\
\hline & 1 & Labour (Unskilled) & Day & 16.50 & 238.07 & 3928.16 \\
\hline & \multicolumn{5}{|c|}{ Total } & 3928.16 \\
\hline & \multicolumn{5}{|c|}{ Total per $\mathrm{m}^{3}$} & 62.85 \\
\hline (b) & \multicolumn{6}{|c|}{ Machinery } \\
\hline & Sl. No. & Item & Unit & Quantity & Rate (Rs.) & $\begin{array}{l}\text { Amount } \\
\text { (Rs.) }\end{array}$ \\
\hline & 1 & Plant & Day & 1.00 & 10000.00 & 10000.00 \\
\hline & 2 & Tipper & Day & 3.60 & 1600.00 & 5760.00 \\
\hline & 3 & Loader & Day & 1.00 & 900.00 & 900.00 \\
\hline & 4 & Road Roller & Day & 3.60 & 1000.00 & 3600.00 \\
\hline & \multicolumn{5}{|c|}{ Total } & 20260.00 \\
\hline & \multicolumn{5}{|c|}{ Total per $\mathrm{m}^{3}$} & 324.16 \\
\hline \multirow[t]{3}{*}{ (c) } & \multicolumn{6}{|c|}{ Material Cost } \\
\hline & Sl. No. & Item & Unit & Quantity & Rate (Rs.) & $\begin{array}{l}\text { Amount } \\
\text { (Rs.) }\end{array}$ \\
\hline & 1 & Bitumen & $\mathrm{T}$ & 8.09 & 33000.00 & 266970.00 \\
\hline
\end{tabular}




\begin{tabular}{|l|l|l|l|l|l|l|} 
& 2 & Coarse Aggregate & $\mathrm{m}^{3}$ & 55.78 & 647.80 & 36134.28 \\
\hline & 3 & Fine Aggregate & $\mathrm{m}^{3}$ & 29.50 & 707.00 & 20856.50 \\
\hline & 4 & Lime & $\mathrm{T}$ & 4.20 & 1800.00 & 7560.00 \\
\hline & Total & 331520.00 \\
\hline & Total per $\mathrm{m}^{3}$ & 5304.32 \\
\hline (d) & $\begin{array}{l}\text { Contractor's Profit and Overhead Charges @ } 12.5 \% \text { on } \\
(\mathrm{a})+(\mathrm{b})+(\mathrm{c})\end{array}$ & 711.42 \\
\hline & Grand Total $(\mathrm{a}+\mathrm{b}+\mathrm{c}+\mathrm{d})$ & 6402.75 \\
\hline
\end{tabular}

Table 16 Thickness and cost of construction of various layers

\begin{tabular}{|c|c|c|c|c|c|c|c|c|}
\hline \multirow[b]{2}{*}{ 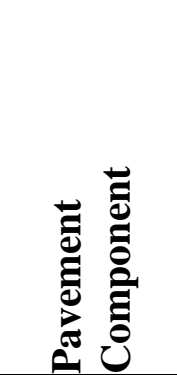 } & \multirow[b]{2}{*}{ 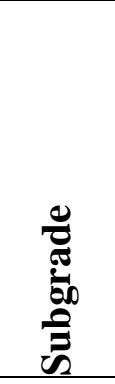 } & \multicolumn{4}{|c|}{ Sub-base Course } & \multirow[b]{2}{*}{ 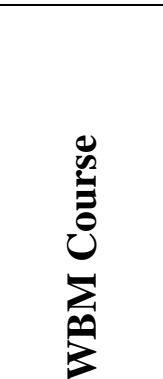 } & \multirow[b]{2}{*}{ 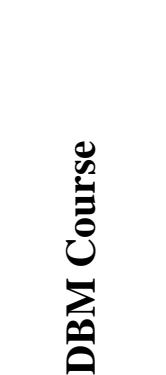 } & \multirow[b]{2}{*}{ 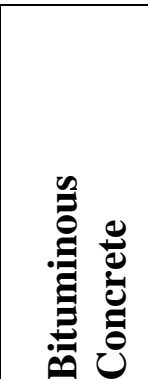 } \\
\hline & & $\sum_{\mathcal{D}}$ & 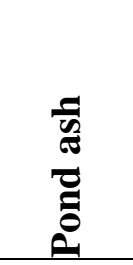 & 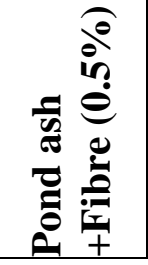 & 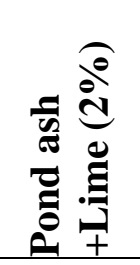 & & & \\
\hline $\begin{array}{l}\text { Thickness } \\
(\mathrm{mm})\end{array}$ & 500 & \multicolumn{4}{|l|}{200} & 250 & 135 & 50 \\
\hline $\begin{array}{l}\text { Cost per } \\
\mathrm{m}^{3} \text { (Rs.) }\end{array}$ & 111.6 & 952.02 & 100.83 & 597.63 & 628.46 & 1371.14 & 5429.45 & 6402.75 \\
\hline
\end{tabular}

Table 17 Percentage saving in cost for $1 \mathrm{~km}$ long pavement section with stabilized subbase layer for the same service life

\begin{tabular}{|c|c|c|c|c|c|c|c|c|c|c|}
\hline $\begin{array}{l}\text { Sl. } \\
\text { No. }\end{array}$ & \multicolumn{2}{|c|}{$\begin{array}{l}\text { Pavement } \\
\text { Component }\end{array}$} & $\begin{array}{l}\text { Top } \\
\text { width } \\
\text { (m) }\end{array}$ & $\begin{array}{l}\text { Bottom } \\
\text { width } \\
\text { (m) }\end{array}$ & $\begin{array}{l}\text { Height } \\
*(\mathbf{m})\end{array}$ & $\begin{array}{l}\text { Volume } \\
\left(\mathbf{m}^{3}\right)\end{array}$ & $\begin{array}{l}\text { Rate per } \\
\mathbf{m}^{3} \text { (Rs.) }\end{array}$ & $\begin{array}{l}\text { Total } \\
\text { Rate } \\
\text { (Rs.) }\end{array}$ & $\begin{array}{l}\text { Total } \\
\text { Cost } \\
(\text { Rs. }) \\
(\mathbf{1 + 2 + 3 +} \\
\mathbf{4 + 5})\end{array}$ & $\begin{array}{l}\text { Saving } \\
\text { in cost } \\
(\%)\end{array}$ \\
\hline 1 & \multicolumn{2}{|c|}{$\begin{array}{l}\text { Bituminous } \\
\text { Course }\end{array}$} & 3.75 & 3.95 & 0.05 & 192.5 & 6402.75 & 1232529 & \multirow[t]{4}{*}{-} & \multirow[t]{4}{*}{-} \\
\hline 2 & \multicolumn{2}{|c|}{ DBM Course } & 3.95 & 4.49 & 0.135 & 569.7 & 5429.45 & 3093158 & & \\
\hline 3 & \multicolumn{2}{|c|}{ WBM Course } & 4.49 & 5.49 & 0.250 & 1247.5 & 1371.14 & 1710497 & & \\
\hline 4 & \multicolumn{2}{|c|}{ Sub-base Course } & 5.49 & & & & & & & \\
\hline (a) & \multicolumn{3}{|c|}{ CSM } & 6.29 & 0.200 & 1178 & 952.02 & 1121480 & & - \\
\hline (b) & \multicolumn{3}{|l|}{ Pond Ash } & 6.75 & 0.315 & 1928 & 100.83 & 194380 & & \\
\hline (c) & \multicolumn{3}{|c|}{ Pond Ash + Fibre $(0.5 \%)$} & 6.07 & 0.145 & 838 & 597.63 & 500874 & & \\
\hline (d) & \multicolumn{3}{|c|}{ Pond Ash + Lime (2\%) } & 6.378 & 0.222 & 1317 & 628.46 & 827901 & & \\
\hline \multirow[t]{4}{*}{5} & \multirow[t]{4}{*}{ Subgrade } & (a) & 6.29 & 8.29 & \multirow[t]{4}{*}{0.5} & 3645 & \multirow[t]{4}{*}{111.60} & 406782 & 7564446 & - \\
\hline & & (b) & 6.75 & 8.75 & & 3875 & & 432450 & 6663014 & 11.92 \\
\hline & & (c) & 6.07 & 8.07 & & 3535 & & 394506 & 6931564 & 8.37 \\
\hline & & (d) & 6.378 & 8.378 & & 3689 & & 411692.4 & 7275777 & 3.82 \\
\hline
\end{tabular}

* Equivalent height of same SLR 


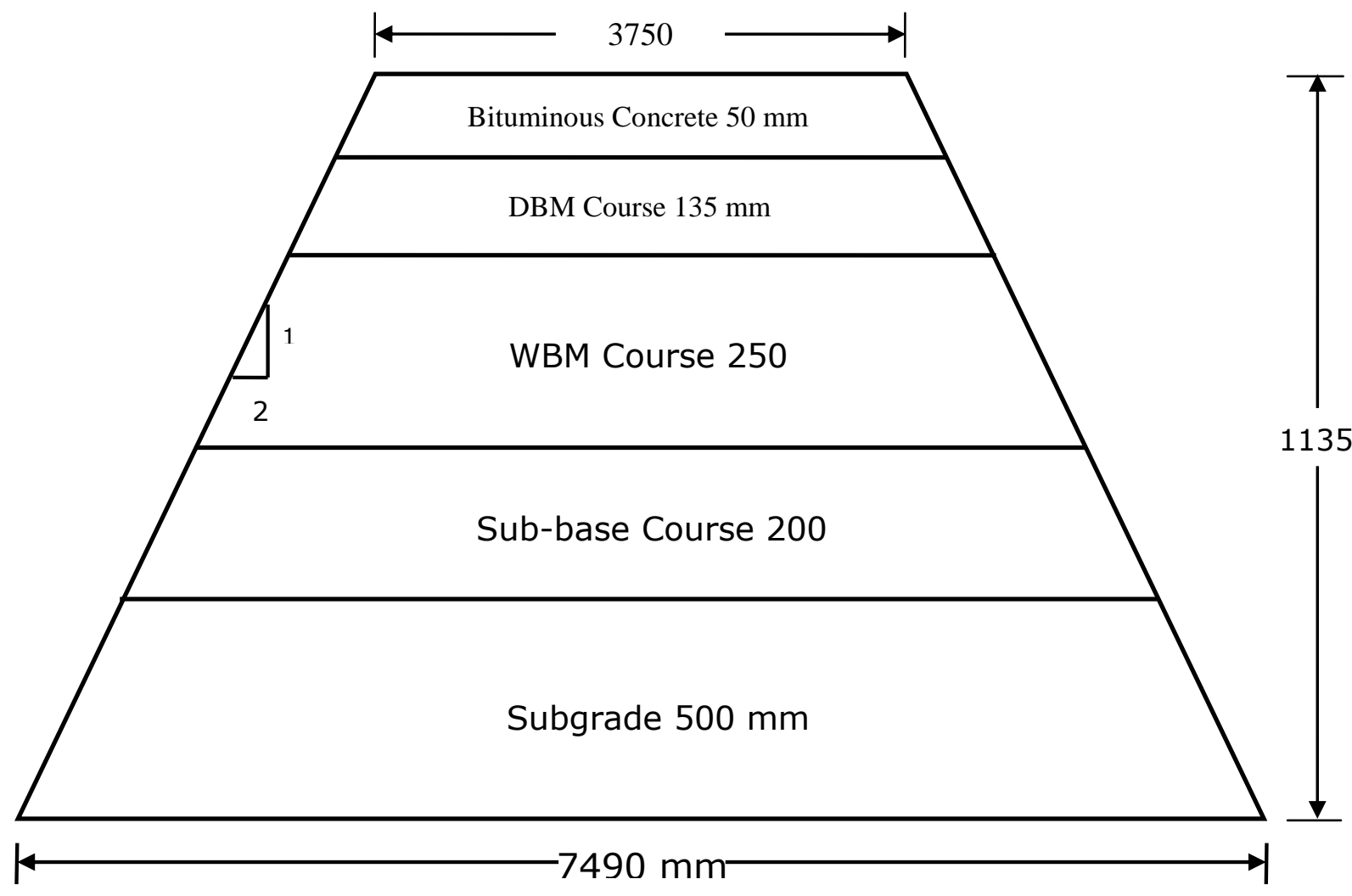

Fig. 1 Pavement structure 


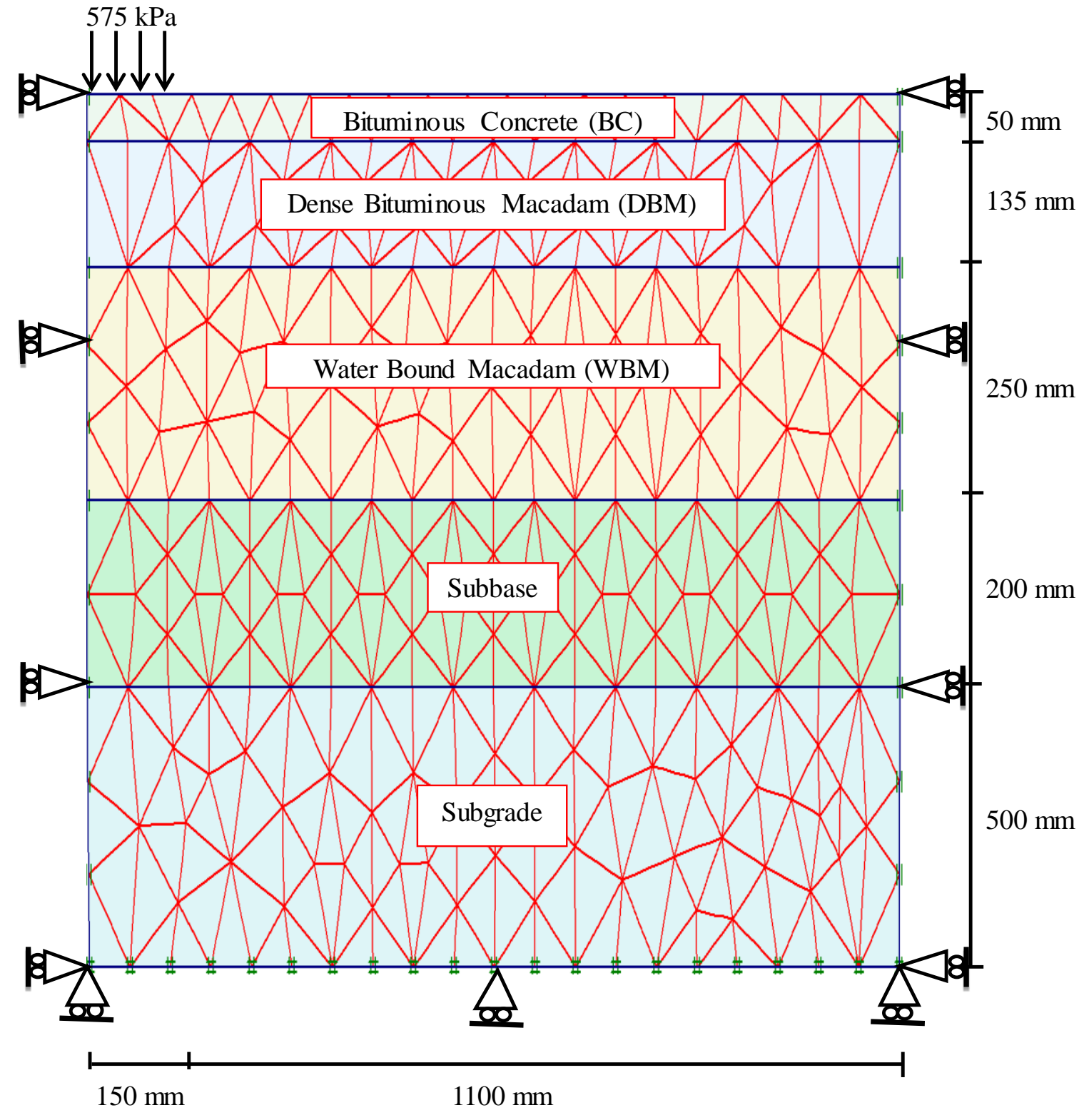

Fig. 2 Finite Element Discretization of pavement section 


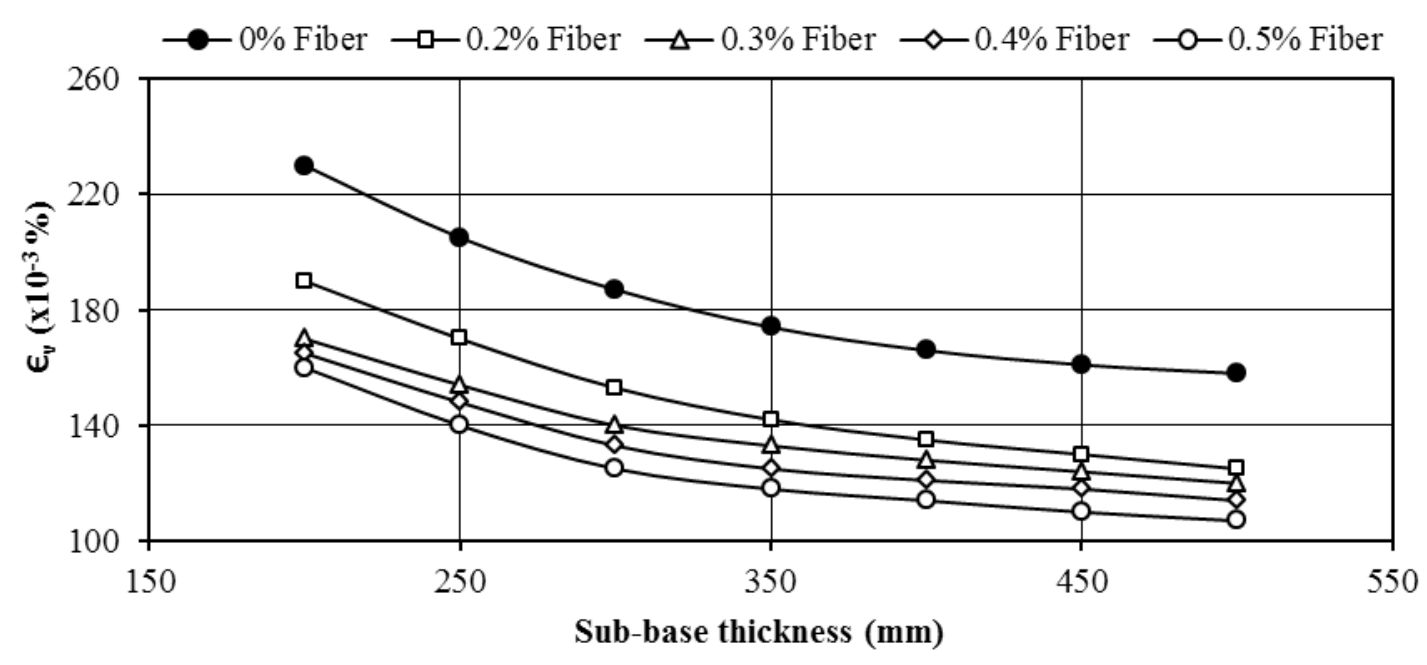

(a)

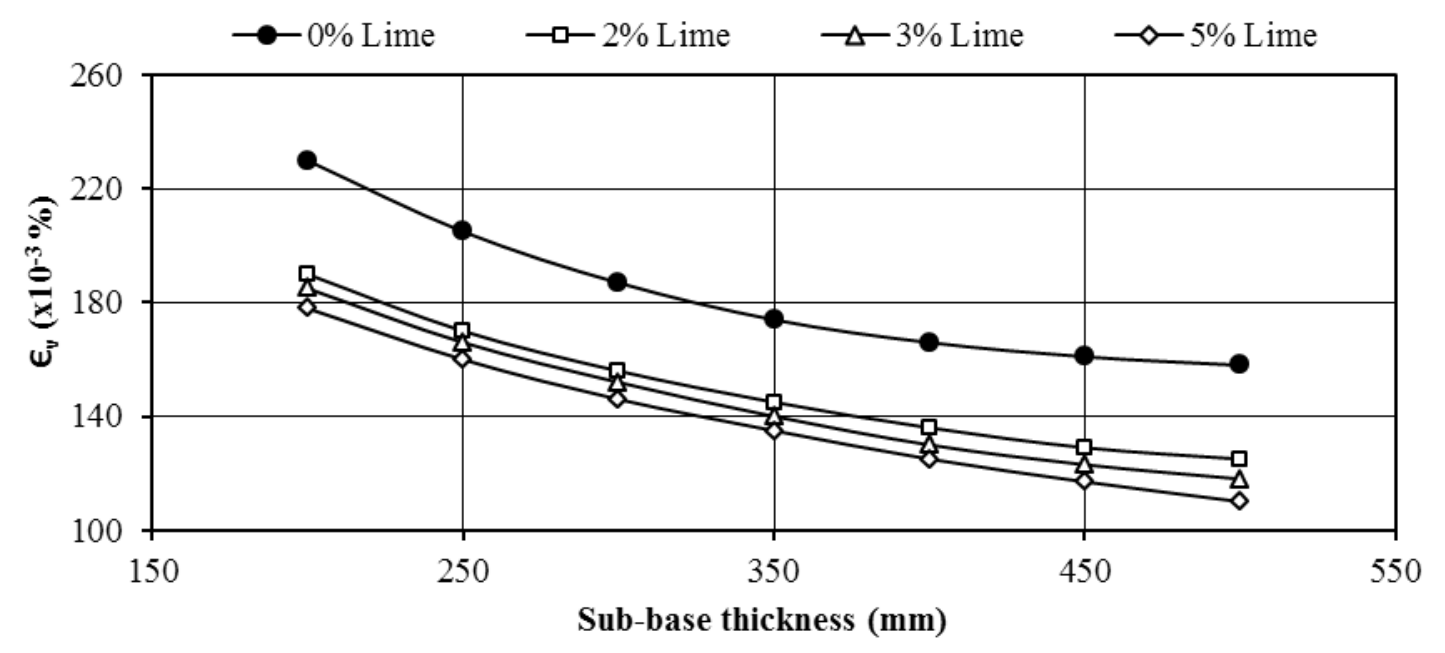

(b)

Fig. 3 Vertical compressive strain-subbase thickness behaviour of pond ash mixed with

(a) Fibre and (b) Lime 


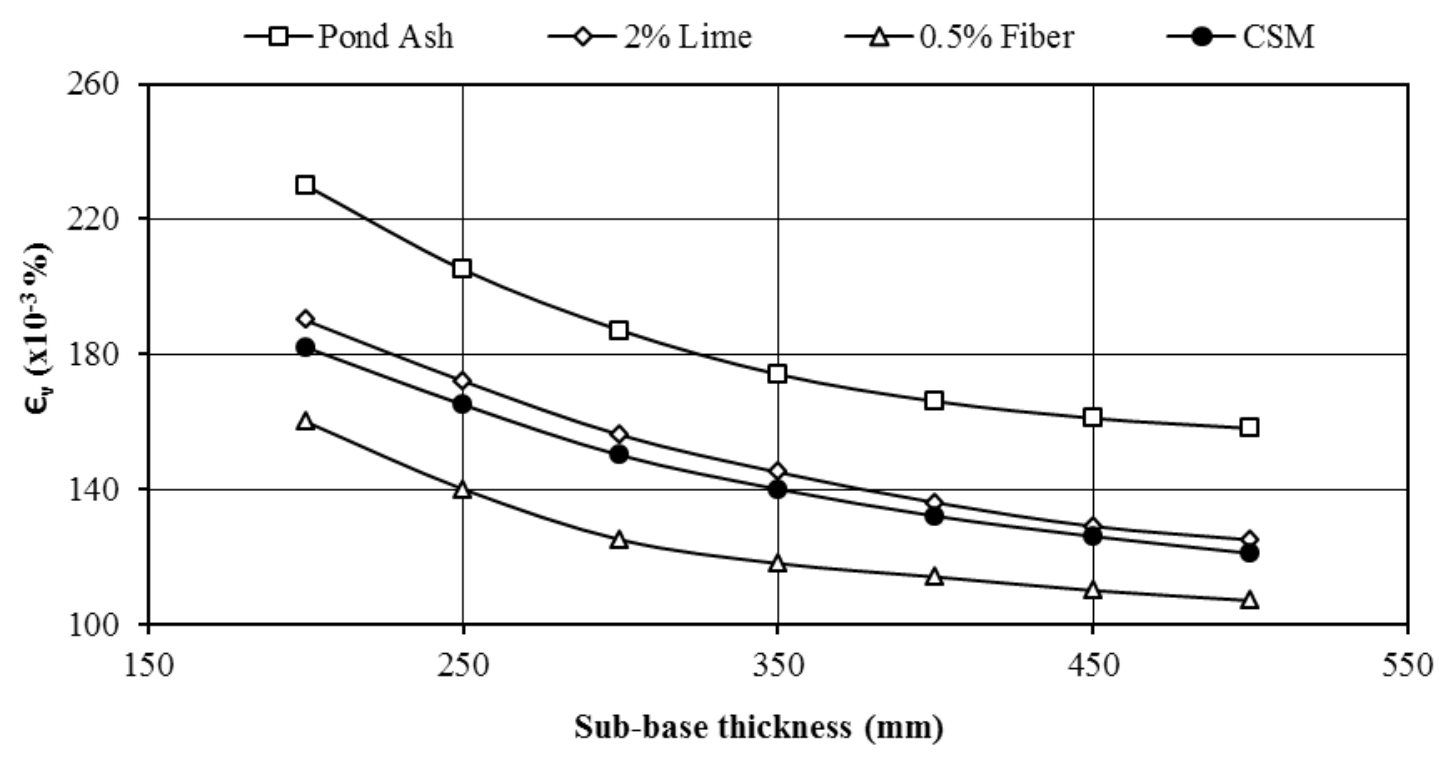

(a)

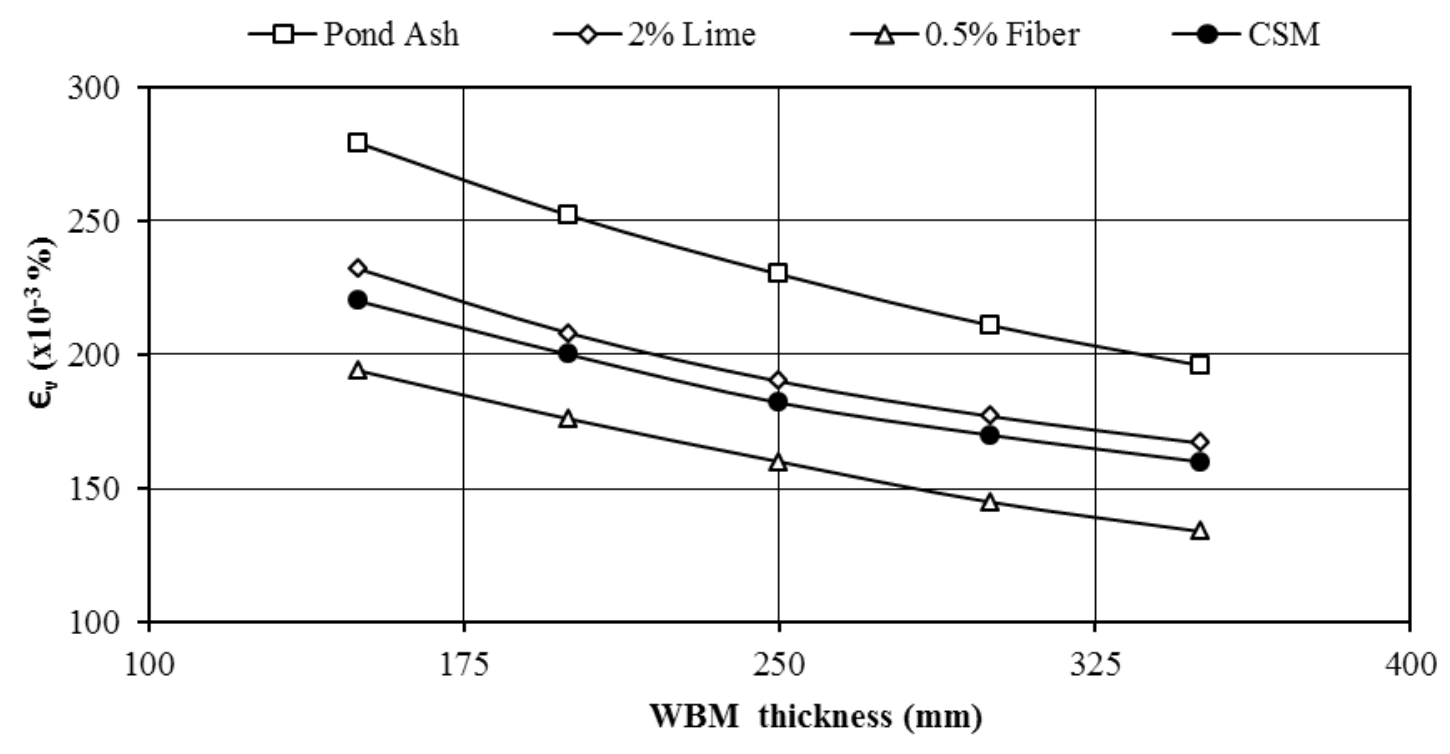

(b) 


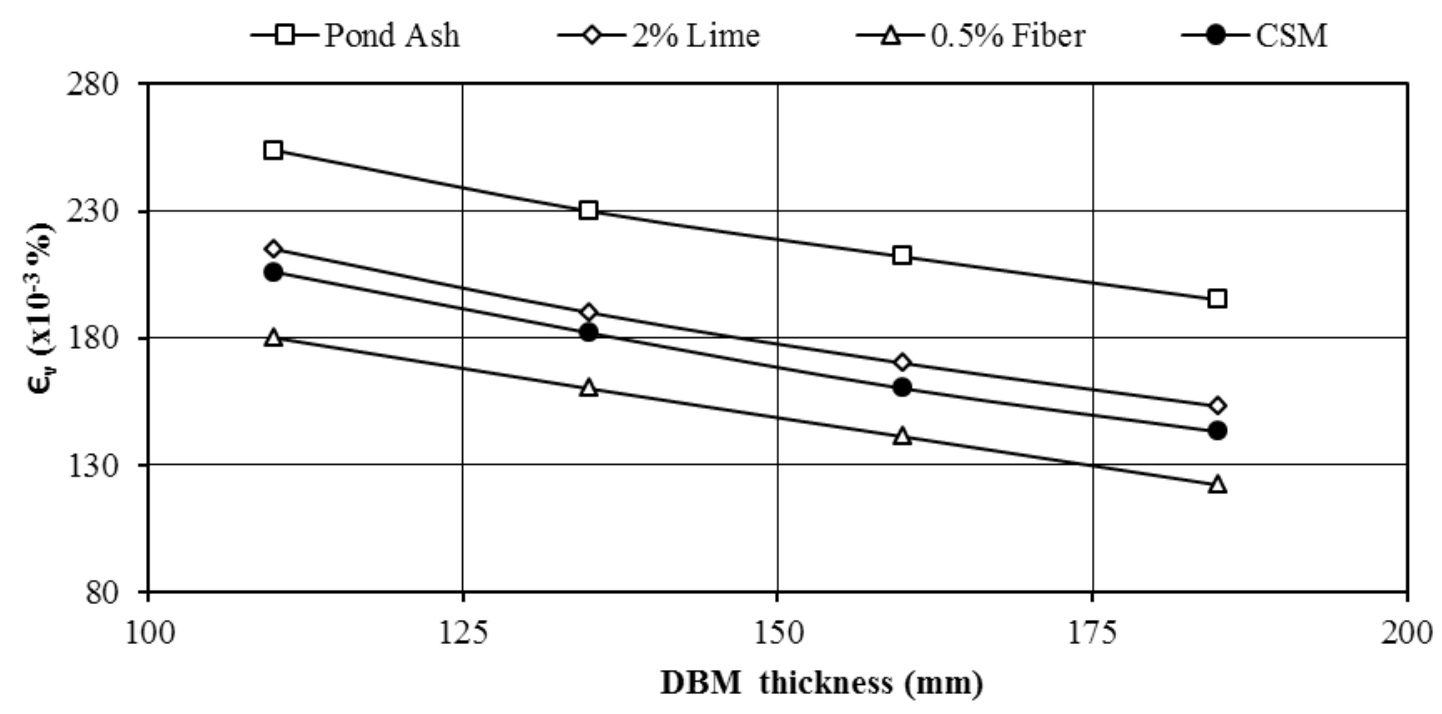

(c)

Fig. 4 Comparison of variation of vertical compressive strain with(a) Subbase, (b) WBM and (c) DBM thickness behaviour of pond ash and its mixes 


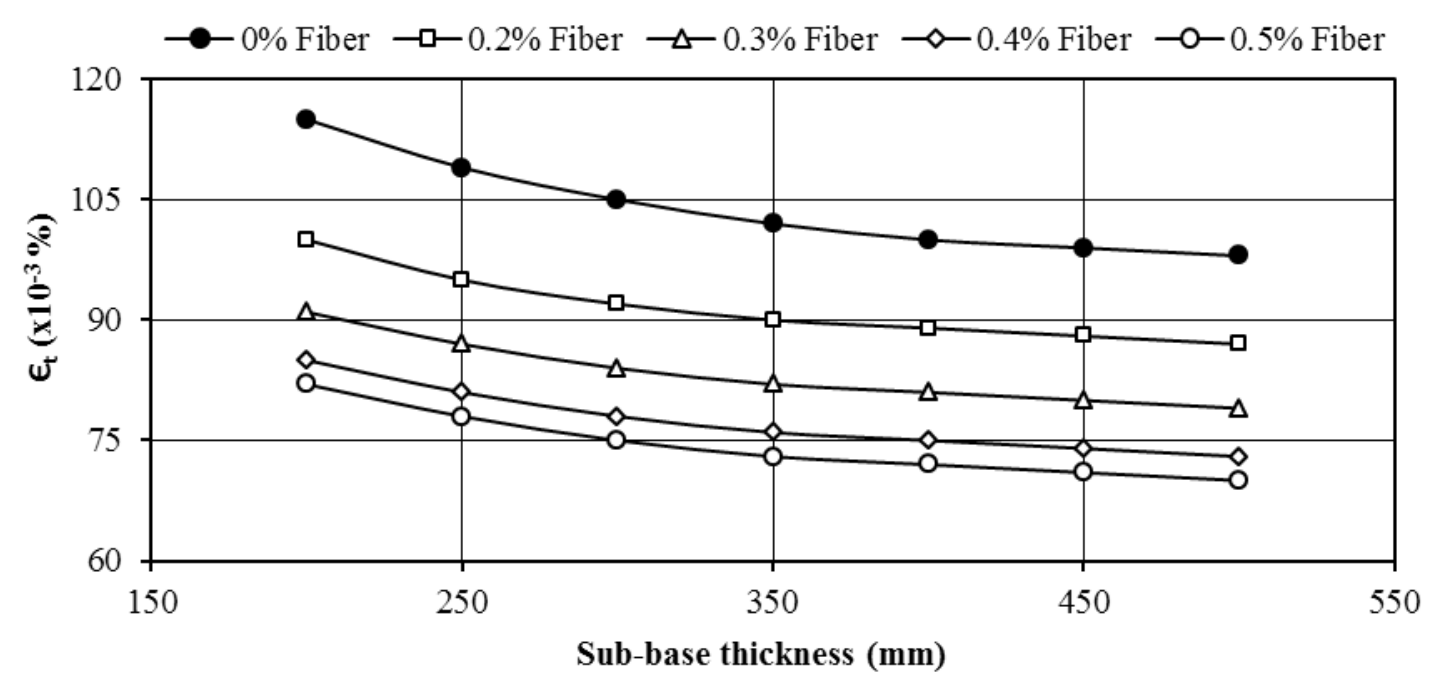

(a)

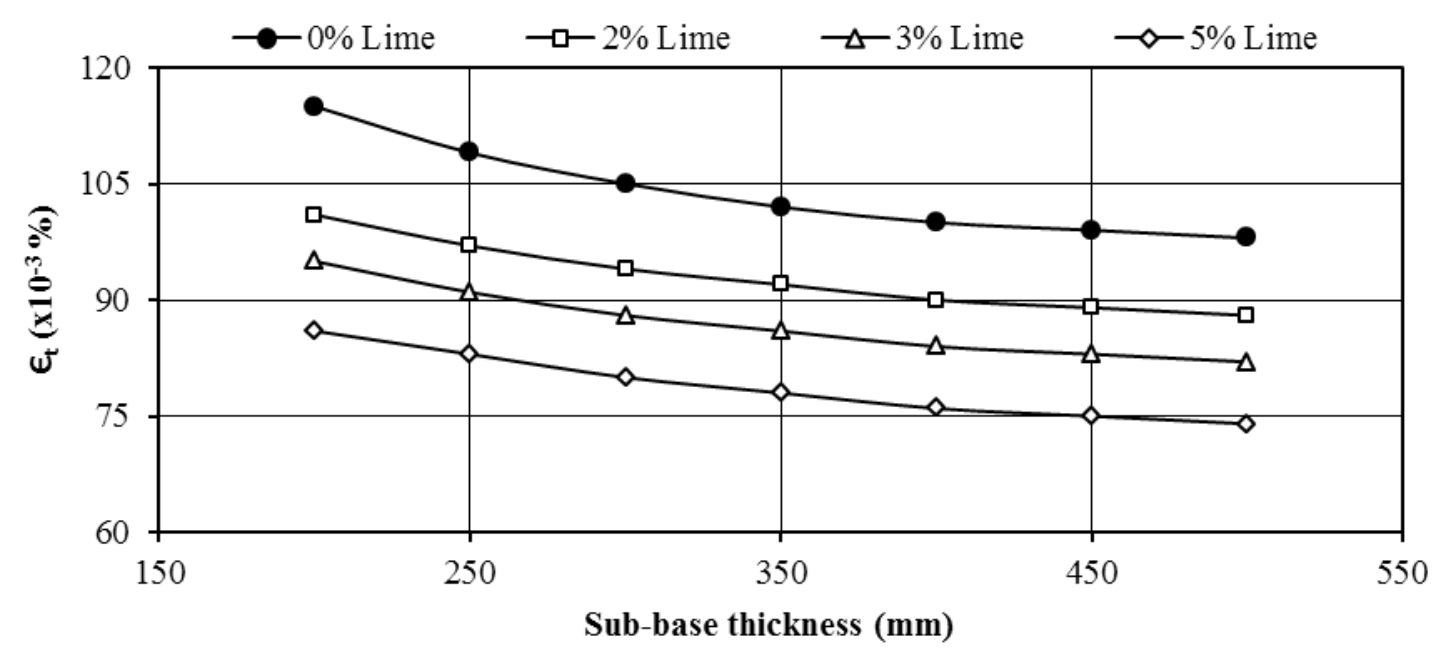

(b)

Fig. 5 Tensile strain at the bottom of the DBM and subbase thickness behaviour of pond ash mixed with (a) Fibre and (b) Lime 


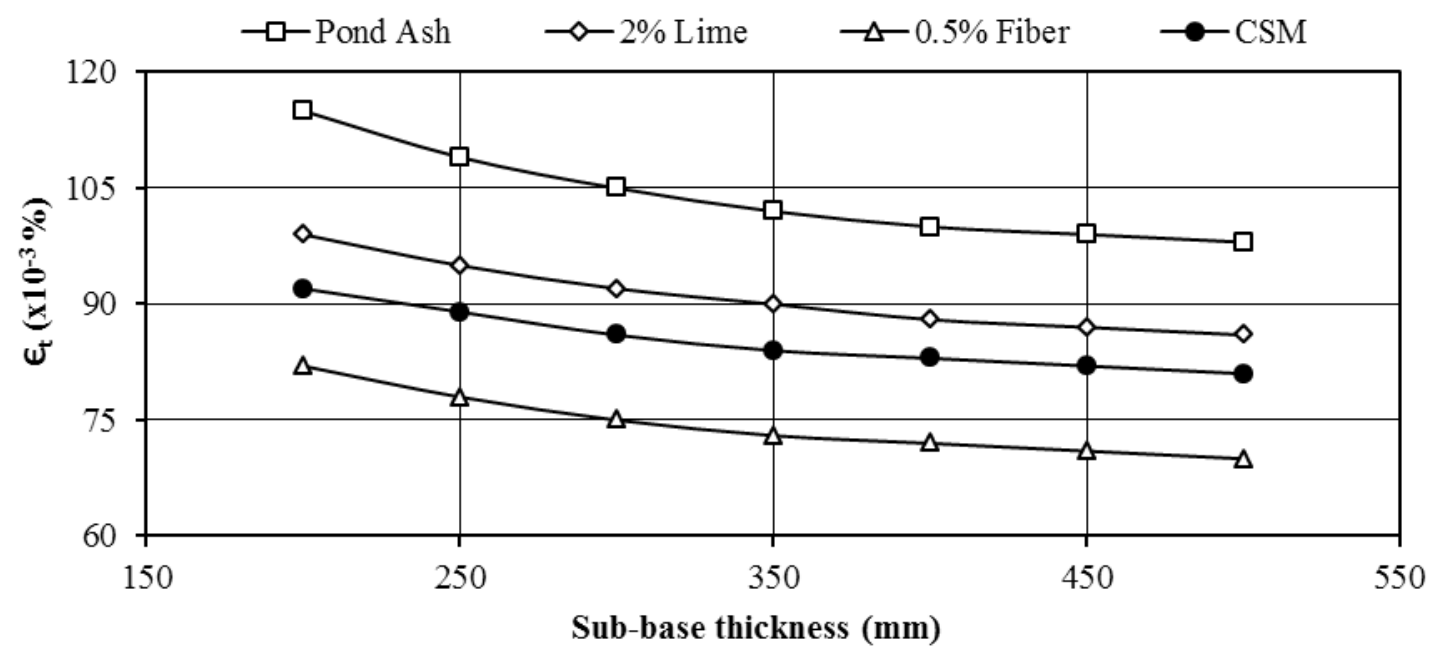

Fig. 6 Comparison of variation of tensile strain at the bottom of the DBM as a function of the subbase thickness of pond ash and its mixes

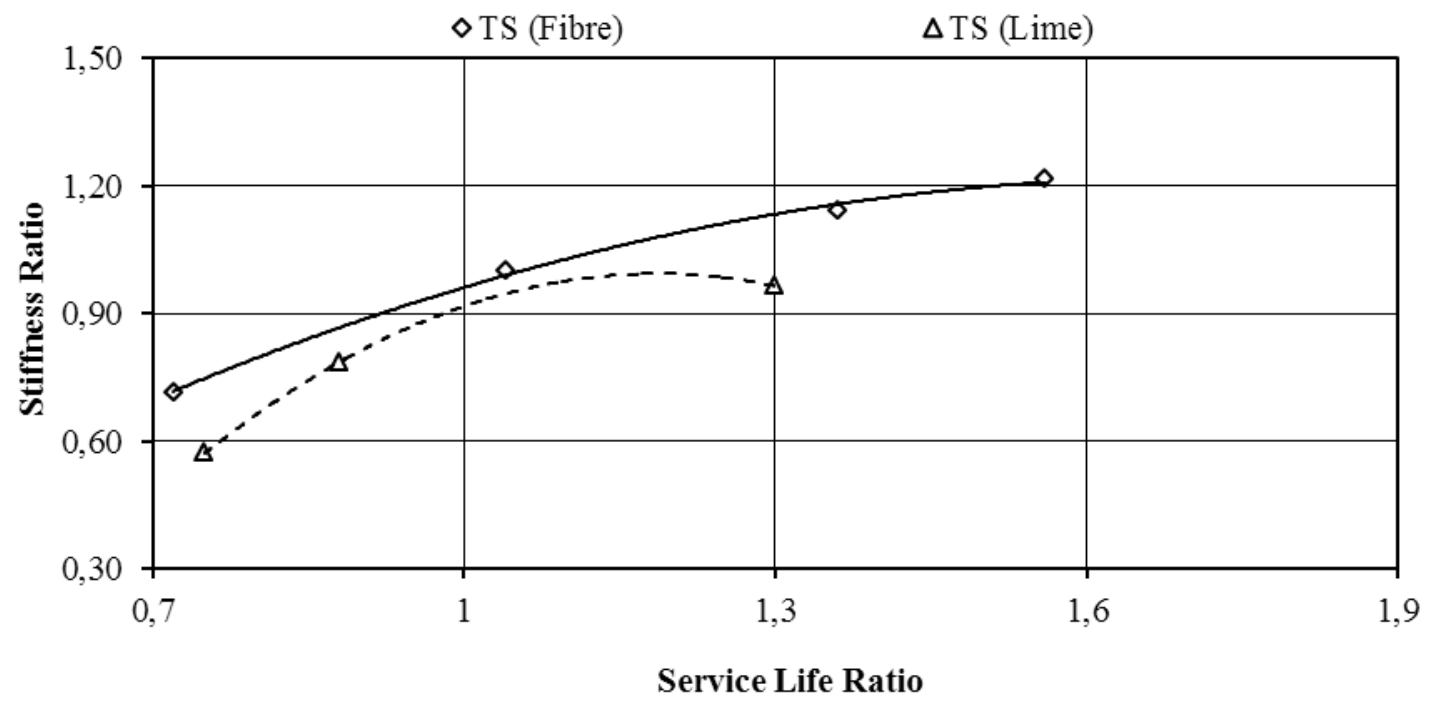

Fig. 7 Variation of stiffness ratio (Ash:CSM) with service life ratio of pond ash mixed with fibre and lime 


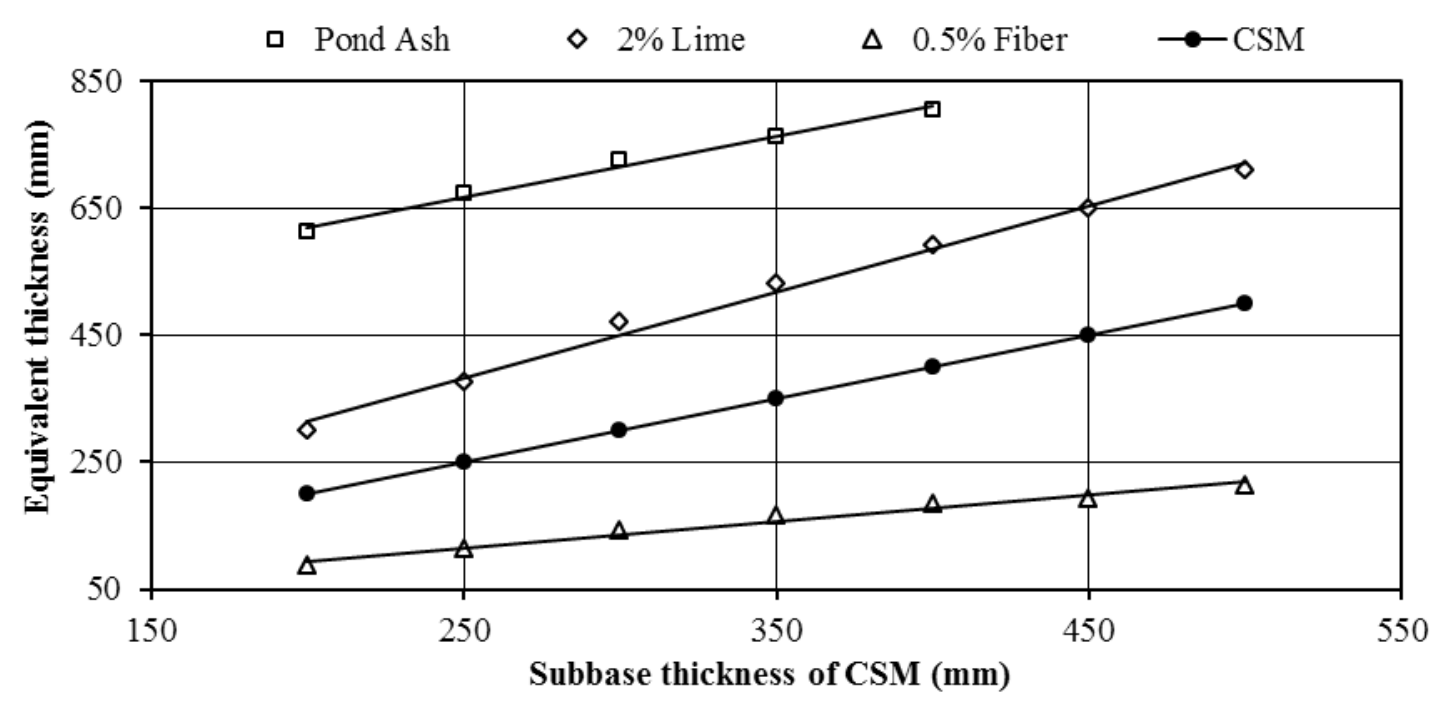

(a)

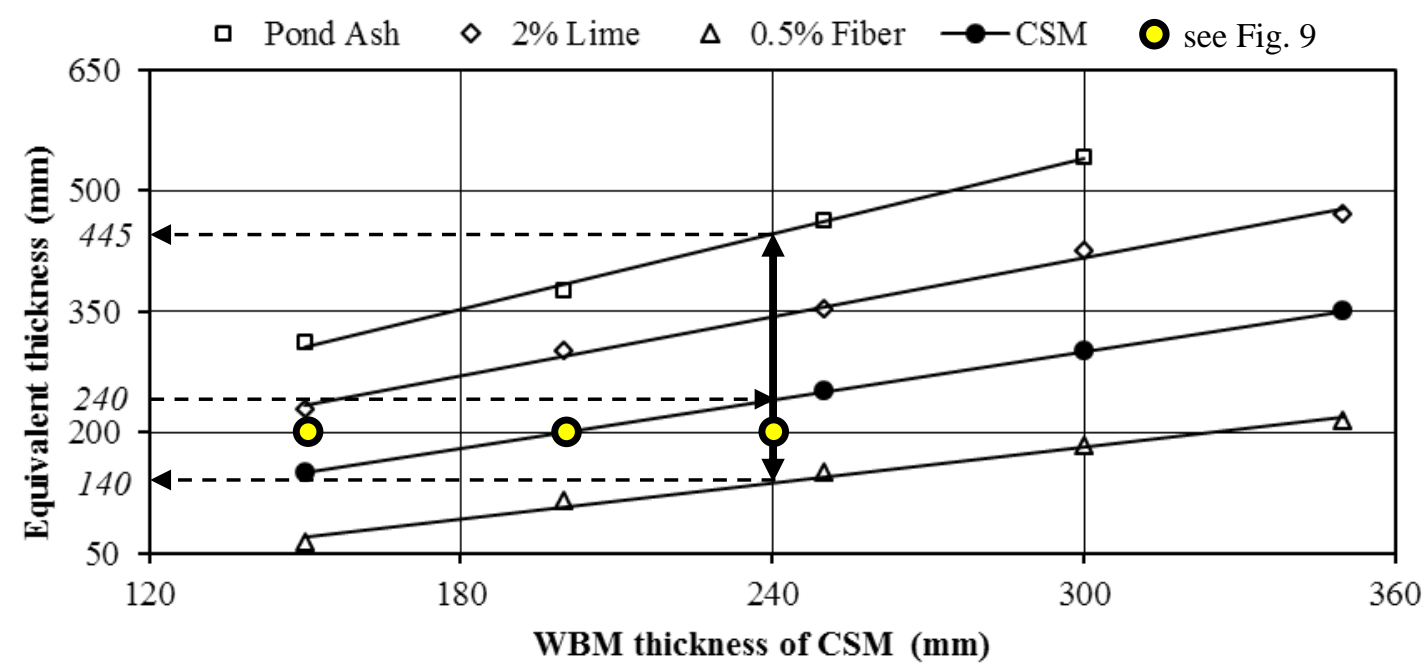

(b)

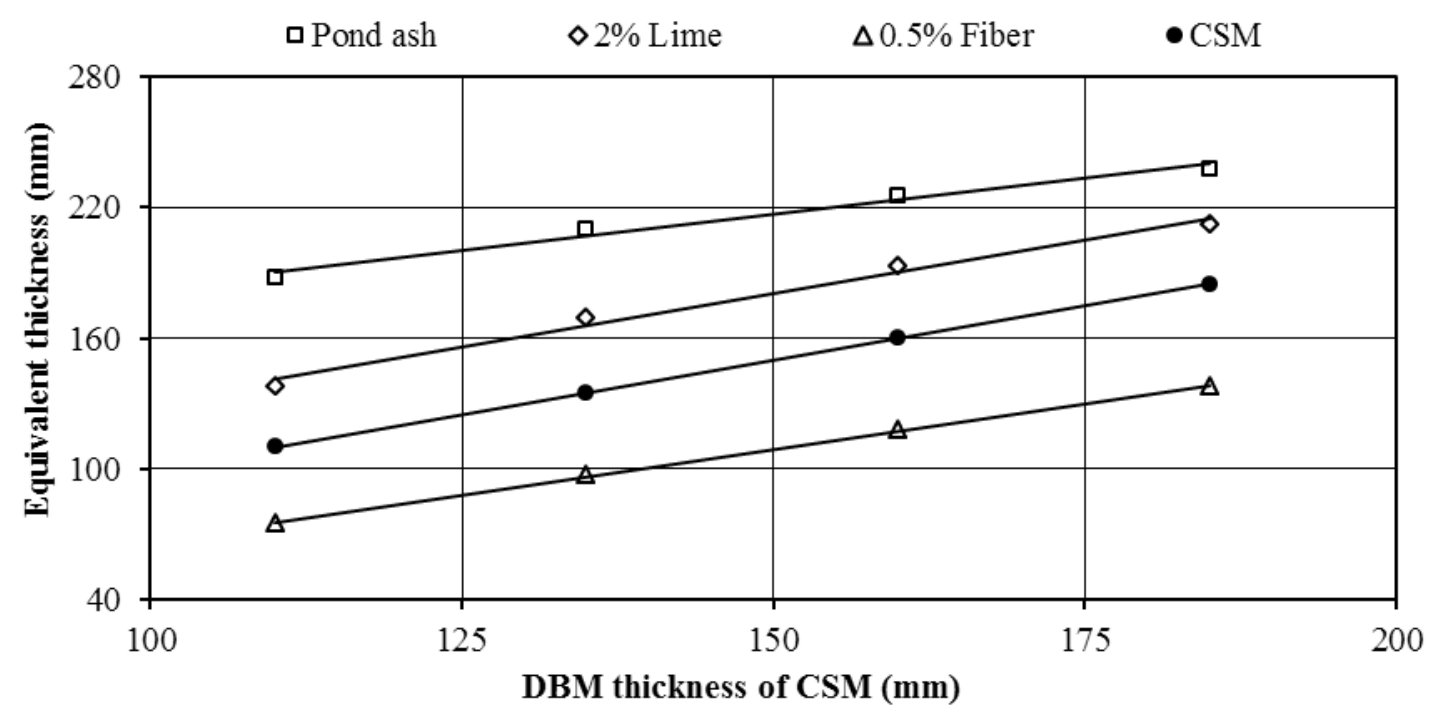

(c) 
Fig. 8 Variation of equivalent thickness of (a) Subbase (b) WBM (c) DBM of different materials for same service life when pond ash mixture is used as subbase material

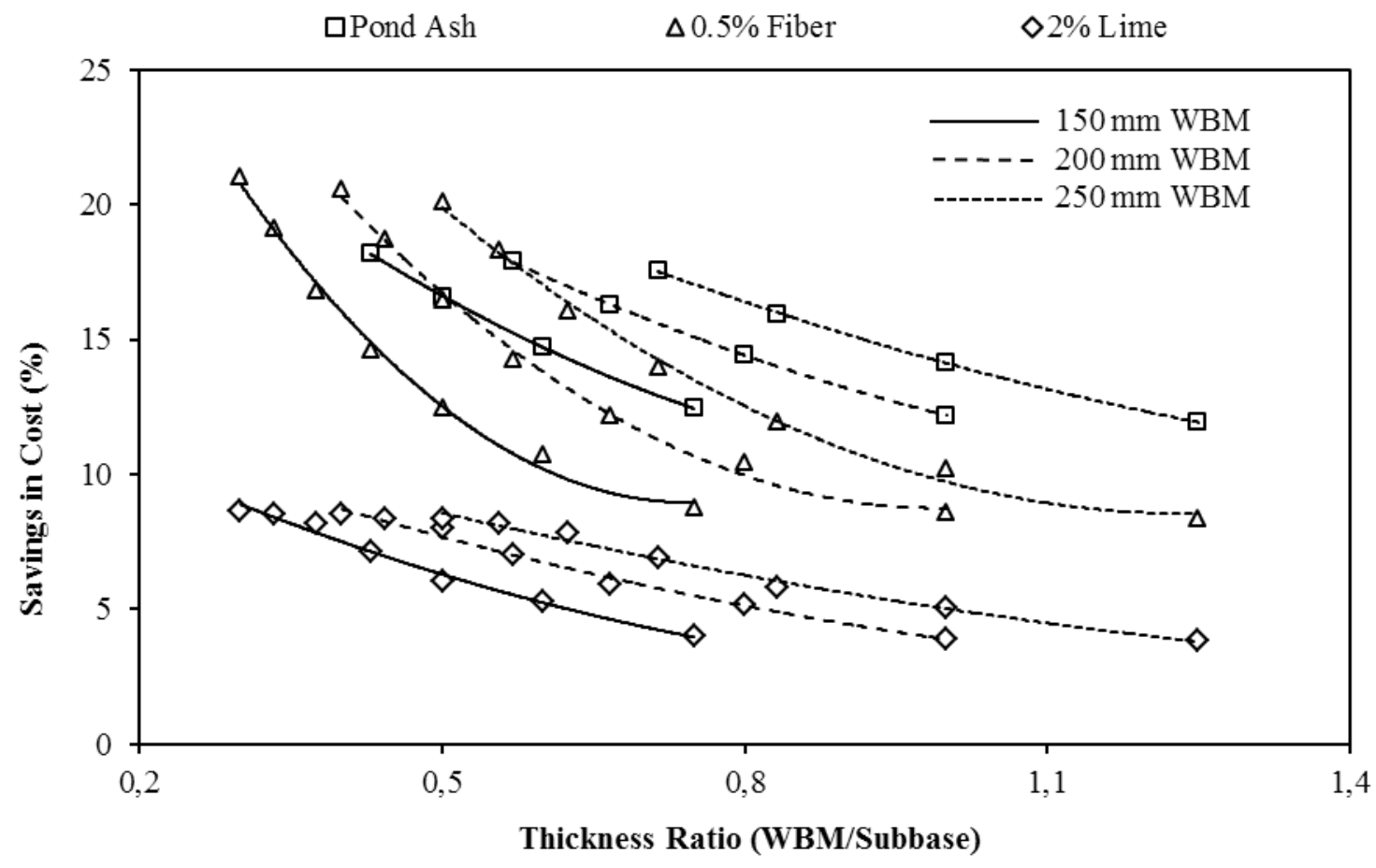

Fig. 9 Comparison of percentage saving of cost and thickness ratio considering vertical strain at the top of subgrade 


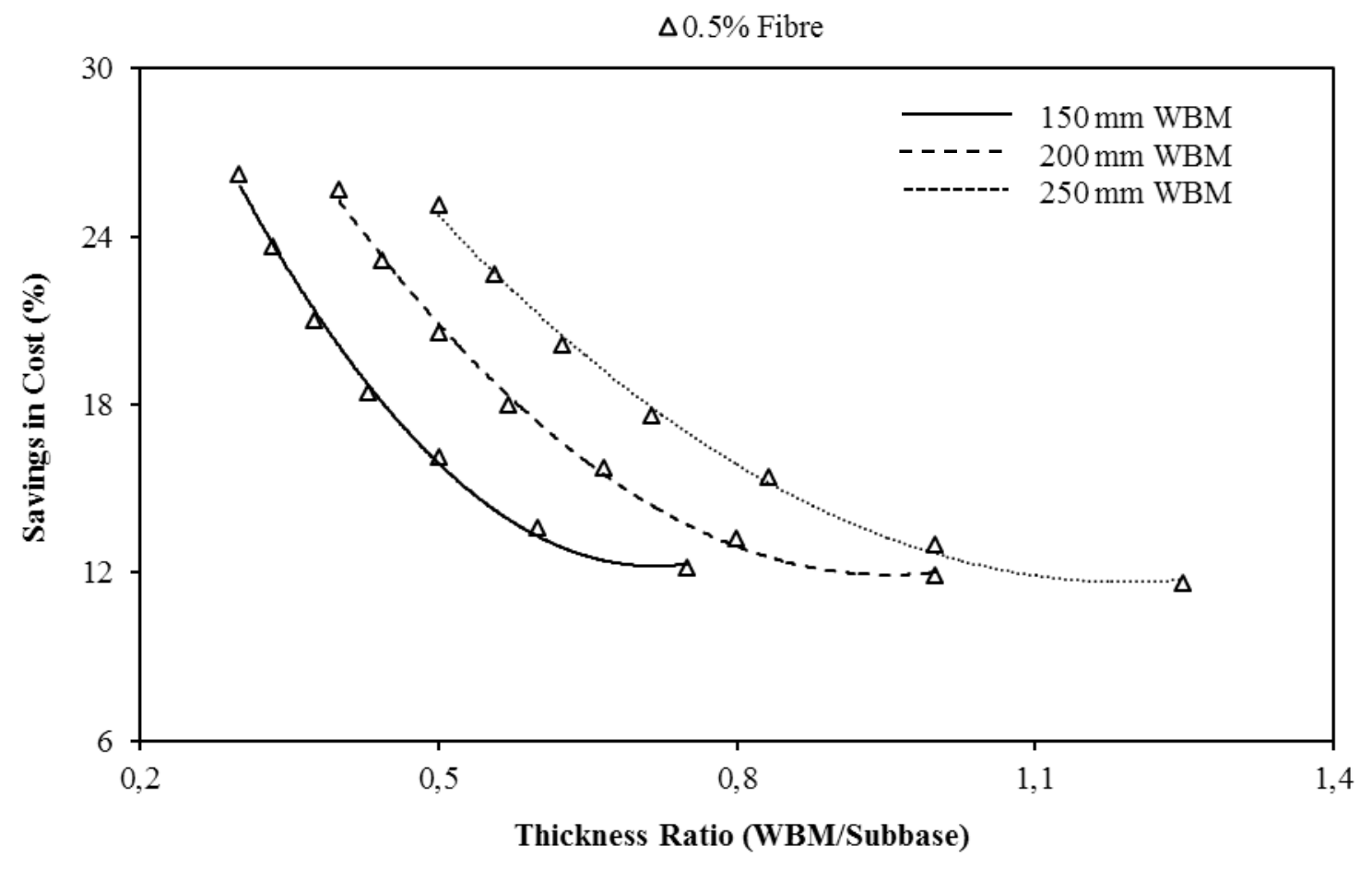

Fig. 10 Comparison of percentage saving of cost and thickness ratio considering tensile strain at the bottom of DBM 